Article

\title{
Key Role of Precursor Nature in Phase Composition of Supported Molybdenum Carbides and Nitrides
}

\author{
Zdeněk Tišler®, Romana Velvarská, Lenka Skuhrovcová, Lenka Pelíšková and \\ Uliana Akhmetzyanova *(D) \\ Unipetrol Centre for Research and Education, a.s, Areál Chempark 2838, Záluží 1, 43670 Litvínov, \\ Czech Republic; Zdenek.Tisler@unicre.cz (Z.T.); Romana.Velvarska@unicre.cz (R.V.); \\ Lenka.Skuhrovcova@unicre.cz (L.S.); Lenka.Peliskova@unicre.cz (L.P.) \\ * Correspondence: uliana.akhmetzyanova@unicre.cz; Tel.: +420-471-122-238
}

Received: 18 December 2018; Accepted: 24 January 2019; Published: 29 January 2019

check for updates

\begin{abstract}
In this work, we studied the effect of molybdenum precursors and the synthesis conditions on the final phase composition of bulk and supported molybdenum carbides and nitrides. Ammonium heptamolybdate, its mixture with hexamethylenetetramine, and their complex were used as the precursors at different temperatures. It was investigated that the synthesis of the target molybdenum nitrides strongly depended on the structure of the precursor and temperature conditions, while the synthesis of carbide samples always led to the target phase composition. Unlike the carbide samples, where the $\alpha-\mathrm{Mo}_{2} \mathrm{C}$ phase was predominant, the mixture of $\beta-\mathrm{Mo}_{2} \mathrm{~N}, \mathrm{MoO}_{2}$ with a small amount of metal molybdenum was generally formed during the nitridation. All supported samples showed a very good dispersion of the carbide or nitride phases.
\end{abstract}

Keywords: Molybdenum nitride; molybdenum carbide; hexamethylenetetramine

\section{Introduction}

There are three types of bonding between the transition metal and carbon or nitrogen atoms: metal bonding (metal-metal), covalent bonding (metal and non-metal), and ionic bonding (charge between metal and non-metal) [1]. The special crystal structure of transition metal carbides and nitrides is created by inserting carbon or nitrogen into the metal-metal bond is what makes its distance longer than the original. This special bond has exclusive electronic properties, which provide catalytic activity similar to the platinum group metals $(\mathrm{Pt}, \mathrm{Pd}, \mathrm{Ru}$, etc.) in various reactions [2]. Molybdenum carbides exist in three basic forms: a face-centered cubic (fcc, $\alpha-\mathrm{MoC}_{1-\mathrm{x}}$ ), a hexagonal closed packed (hcp, $\beta-\mathrm{Mo}_{2} \mathrm{C}$ ), and a simple hexagonal (hex, MoC) structure, while molybdenum nitrides mainly have a cubic structure (fcc, $\left.\gamma-\mathrm{Mo}_{2} \mathrm{~N}\right)$ [3].

Molybdenum carbides are widely used as catalysts due to their activity in many reactions, particularly in the water gas shift reaction, deoxygenation, denitrification, desulfurization, oxidation, partial oxidation, hydrotreating (HDS, HDO, HDN), dehydrogenation, isomerization, hydrogenolysis, hydrodemetallization, and methane reforming [4]. Molybdenum nitrides possess a series of unique and superior catalytic properties for HDS, HDO, HDN [4,5], and electrochemical catalysis [6,7]. Possible difficulties in the application of these types of catalysts that may appear are most often related to obtaining those materials with high specific surface areas (usually less than $10 \mathrm{~m}^{2} / \mathrm{g}$ ) or high porosity. However, these parameters may be varied by changing of synthesis conditions.

High surface area $\mathrm{Mo}_{2} \mathrm{~N}$ and $\mathrm{Mo}_{2} \mathrm{C}$ are synthesized by various methods [8,9]: (a) Direct reaction between metal and non-metal; (b) reaction of metal oxide in the presence of solid carbon; (c) reaction of metal or compounds with gas phase reagent; (d) temperature-programmed methods; (e) reaction between metal oxide vapor and solid carbon under vacuum; (f) pyrolysis of an organometallic complex 
under $\mathrm{H}_{2}$, and other methods where thin carbide films are obtained by chemical vapor deposition [10], plasma method, or electrochemical reduction [11-13].

The oldest method for synthesis of molybdenum carbides is the direct reaction of metals or metal oxides with elemental carbon in a vacuum or reducing atmosphere of $\mathrm{H}_{2}$ at $1200-2000{ }^{\circ} \mathrm{C}$, and a self-propagating high-temperature synthesis. The indicated methods produce only bulk metal carbides with low specific surface areas [14].

Using carbon black (CB) as a carburizing agent is a completely new technique for molybdenum carbide preparation. In this synthesis, a mixture of ammonium heptamolybdate (AHM) solution with a $\mathrm{CB}$ suspension in acetone is heated up to $350{ }^{\circ} \mathrm{C}$ in the air. Then, the obtained $\mathrm{MoO}_{3} / \mathrm{CB}$ precursor is carbidized in a gas mixture of $\mathrm{CH}_{4} / \mathrm{H}_{2}$ [15-17]. Recent publications reported an application of organic compounds (ethylene glycol, glucose, sucrose, polymers) as a source of carbon [18-21]. The organic material is dissolved in water and mixed with molybdic acid or AHM to obtain cubic molybdenum carbides with small crystal domain sizes at a high temperature. In the past decade, a synthesis of metal carbides with the use of mechanical activation was also published [22-25]. For the synthesis of molybdenum carbides using mechanical activation, CB was impregnated with an aqueous solution of AHM by the incipient wetness method. Synthesized materials showed a good mechanical resistance and relatively high specific surface area (about $125 \mathrm{~m}^{2} / \mathrm{g}$ ).

Preparation of molybdenum nitrides is based mainly on ammonia reduction of molybdenum-containing precursors. Thereby, a high surface area $\mathrm{Mo}_{2} \mathrm{~N}\left(116 \mathrm{~m}^{2} / \mathrm{g}\right)$ was prepared through nitridation of $\mathrm{MgMoO}_{4}$ in a flow of $\mathrm{N}_{2} / \mathrm{H}_{2}$ gas mixture at $800{ }^{\circ} \mathrm{C}$ [26]. However, the general method for synthesis of molybdenum carbides and nitrides is temperature-programmed reduction (TPR), where carburization/nitridation is carried out by a reaction between molybdenum oxide $\left(\mathrm{MoO}_{3}\right.$ or $\left.\mathrm{MoO}_{2}\right)$ and a gas mixture, such as $\mathrm{H}_{2}$ with carbon- $\left(\mathrm{CH}_{4}, \mathrm{C}_{2} \mathrm{H}_{6}, \mathrm{C}_{3} \mathrm{H}_{8}\right.$, toluene, etc. $)$ or nitrogen-containing gases $\left(\mathrm{NH}_{3}, \mathrm{~N}_{2}\right)$.

Different synthesis conditions can also change molybdenum structures, as in the case of (i) a hexagonal closed packed form of molybdenum carbide (hcp; $\beta-\mathrm{Mo}_{2} \mathrm{C}$ ) using typical temperature ramps [27-30], (ii) cubic molybdenum carbide phases (fcc; $\alpha-\mathrm{MoC}_{1-\mathrm{x}}$ ) through a special preparation and lower temperatures [31-33], or (iii) a cubic molybdenum nitride phase $\left(\gamma-\mathrm{Mo}_{2} \mathrm{~N}\right)[9,26]$. These methods allow produce not only metal carbides and nitrides as powders or particles, but also supported species [34-36] with a high specific surface area. Molybdenum carbides with a high specific surface area are usually synthesized using AHM as a precursor [37]. AHM is dissolved in water and supplemented with $\mathrm{HCl}$ to precipitate molybdic acid, which is then dried and held in hydrogen flowing at a high temperature $\left(1500^{\circ} \mathrm{C}\right)$. By this method, very well crystallized and phase pure catalysts characterized by a small specific surface area are produced. Enlargement of the surface area can be obtained by a single-step carbidization of the precursor $\left(\mathrm{AHM}\right.$ or $\mathrm{MoO}_{3}$ ). When a mixture of $\mathrm{CH}_{4} / \mathrm{H}_{2}$ is used as the reaction gas and temperature-programmed heating is up to $500-900{ }^{\circ} \mathrm{C}$ for 3 to $6 \mathrm{~h}[15,38-41]$, a hexagonal phase of molybdenum carbide is formed from AHM, while oxides can be transformed into other carbide structures using toluene as the carburizing agent [30,31,42]. The selected ramps and temperatures allow the formation of the cubic phase instead of hexagonal at low temperatures, without the use of any structure stabilizing agents.

In a number of studies, molybdenum nitride and carbide have been prepared by a thermal treatment of single-source precursors. It is a simple and effective method to obtain $\mathrm{Mo}_{2} \mathrm{Cor} \mathrm{Mo}_{2} \mathrm{~N}$ using only hexamethylenetetramine (HMT) as a reducing agent and a carbon or nitrogen source [8,43-46]. Afanasiev [43] studied the thermal decomposition of a precursor synthesized by reacting HMT with AHM. The resultant HMT-AHM precursor complex $\left[(\mathrm{HMT})_{2}\left(\mathrm{NH}_{4}\right)_{4} \mathrm{Mo}_{7} \mathrm{O}_{24} \bullet 2 \mathrm{H}_{2} \mathrm{O}\right]$ was decomposed under an argon atmosphere in the temperature range $550-800{ }^{\circ} \mathrm{C}$. Using this method, crystalline $\mathrm{Mo}_{2} \mathrm{~N}$ was synthesized at the temperature higher than $650{ }^{\circ} \mathrm{C}$, while Wang et al. [45] obtained $\beta-\mathrm{Mo}_{2} \mathrm{C}$ by mixing HMT with HMT-AHM at the 7:1 molar ratio and at $700{ }^{\circ} \mathrm{C}$ in an argon atmosphere.

The main purpose of this study is to gain an understanding of the influence of various preparation methods of a precursor on its final physical, chemical, and textural characteristics. Wang et al. [44] 
have already presented two basic preparation methods. In the first, authors followed the method reported by Afanasiev [43] and obtained $\mathrm{Mo}_{2} \mathrm{C}$, while in the second, they used mechanically mixed AHM and HMT with a molar ratio of 1:4 with obtaining metallic Mo and $\mathrm{MoO}_{2}$. The researchers also described an impact of different parameters in hydrogen thermal treatment preparation of HMT and AHM, namely, AHM:HMT molar ratios, temperature, or heating rates [44]. They reported that pure $\mathrm{Mo}_{2} \mathrm{C}$ was obtained when the molar ratio of precursors AHM and HMT reached 1:4, and nitride, carbide, and carbonitride composite materials were obtained when the molar ratio was 1:2. They showed that $\mathrm{Mo}_{2} \mathrm{~N}$ became a major product phase at a lower temperature $\left(500{ }^{\circ} \mathrm{C}\right)$, and for $\mathrm{Mo}_{2} \mathrm{C}$ a higher temperature $\left(650^{\circ} \mathrm{C}\right)$ was needed.

\section{Materials and Methods}

\subsection{Materials}

Analytical grade ammonium heptamolybdate (AHM), hexamethylenetetramine (HMT), and ammonia solution (25 wt\%) were supplied by Lach-Ner s.r.o. (Neratovice, Czech Republic). The $\gamma-\mathrm{Al}_{2} \mathrm{O}_{3}$ spheres (diameter $2.5 \mathrm{~mm}$ ) were purchased from Sasol (Hamburg, Germany), and extrudates of zeolite Beta, $\mathrm{TiO}_{2}$, and $\mathrm{ZrO}_{2}$ were purchased from Euro Support Manufacturing Czechia, s.r.o. (Litvínov, Czech Republic). Mesoporous silica SBA-15 (powder) and pellets of alkali-activated zeolite foam (AZF) with diameter $5 \mathrm{~mm}$ were synthesized in the laboratory.

\subsection{Preparation of Precursors}

Based on the method reported by Afanasiev [43], the initial HMT-AHM precursor complex was synthesized using $50 \mathrm{~g}$ of AHM and $86 \mathrm{~g}$ of HMT dissolved in $300 \mathrm{~mL}$ and $400 \mathrm{~mL}$ of distilled water, respectively. The solutions were mixed out together and left for $48 \mathrm{~h}$ at $3^{\circ} \mathrm{C}$. The sedimented crystals were separated using a paper filter, rinsed with demineralized water, and dried at room temperature for 3 days. The resulted material was named HMT-AHM 7.5 $\times$. The samples of HMT-AHM $5 \times$ and HMT-AHM 10× with lesser and greater amounts of HMT, correspondingly, were synthesized with the same method.

Mechanically mixed samples of the HMT+AHM (2:1) and HMT+AHM (8:1) precursors were prepared by grinding in a mortar and pestle for 10 min of HMT with AHM in the corresponding molar ratios 2:1 and 8:1. HMT+AHM-S (1:1) and HMT+AHM-S (2:1) precursors with molar ratios 1:1 and 2:1 were synthesized by evaporation of the ammonia solution of HMT with $\mathrm{AHM}$. MoO 3 was prepared by calcination of AHM at $450{ }^{\circ} \mathrm{C}$ for $6 \mathrm{~h}$.

Precursors for the supported samples were prepared by incipient wetness impregnation of the HMT-AHM 7.5 $\times$ ammonia solution on the supports $\mathrm{Al}_{2} \mathrm{O}_{3}, \mathrm{TiO}_{2}, \mathrm{ZrO}_{2}, \mathrm{SBA}, \mathrm{BEA}$, and $\mathrm{AZF}$. $\mathrm{Al}_{2} \mathrm{O}_{3}$, impregnated with HMT+AHM-S (2:1), was signed as $\mathrm{Al}_{2} \mathrm{O}_{3}{ }^{\#}$. To obtain a high content of molybdenum nitride or carbide phase, the impregnation was performed with a saturated solution. The impregnated support from the same batch was used for the carbide and nitride synthesis. In the case of the AZF support after drying at $120^{\circ} \mathrm{C}$ for $6 \mathrm{~h}$, the impregnation was repeated once more.

\subsection{Synthesis of Molybdenum Carbides and Nitrides}

The synthesis of the final nitrides and carbides was carried out in a vertical quartz tubular reactor (UniCRE, Litvínov, Czech Republic) with an internal diameter of $27 \mathrm{~mm}$ and length of $1 \mathrm{~m}$ (Figure 1), heated to the working temperature by a triple-zone electric oven (CLASIC CZ, spol. s.r.o., Řevnice, Czech Republic) that was regulated by a PID (proportional-integral-derivative) controller. Each precursor or the impregnated support was placed in a fritted quartz cuvette and placed in the center of the reactor. Further processing of the precursors was done in several steps:

- Heating $\left(10^{\circ} \mathrm{C} / \mathrm{min}\right)$ of the precursor in the $\mathrm{N}_{2}$ flow $\left(75 \mathrm{~cm}^{3} / \mathrm{min}\right)$ at $200{ }^{\circ} \mathrm{C}$ for $12 \mathrm{~h}$; 
- Heating to the desired temperature (of $10{ }^{\circ} \mathrm{C} / \mathrm{min}$ ) in a working gas flow $\left(75 \mathrm{~cm}^{3} / \mathrm{min}\right.$ ). A mixture of $20 \mathrm{vol} \% \mathrm{H}_{2}$ in $\mathrm{N}_{2}$ was used to prepare nitride samples and a mixture of $20 \mathrm{vol} \% \mathrm{CH}_{4}$ in $\mathrm{H}_{2}$ for the carbide preparation. After reaching the desired temperature, the reaction was run for $3 \mathrm{~h}$;

- Cooling to the room temperature in the working gas flow $\left(75 \mathrm{~cm}^{3} / \mathrm{min}\right)$;

- Flushing the reactor with nitrogen $\left(400 \mathrm{~cm}^{3} / \mathrm{min}\right)$ for $30 \mathrm{~min}$;

- Passivation in $1 \mathrm{vol} \% \mathrm{O}_{2}$ in $\operatorname{Ar}\left(75 \mathrm{~cm}^{3} / \mathrm{min}\right)$ for $2 \mathrm{~h}$.

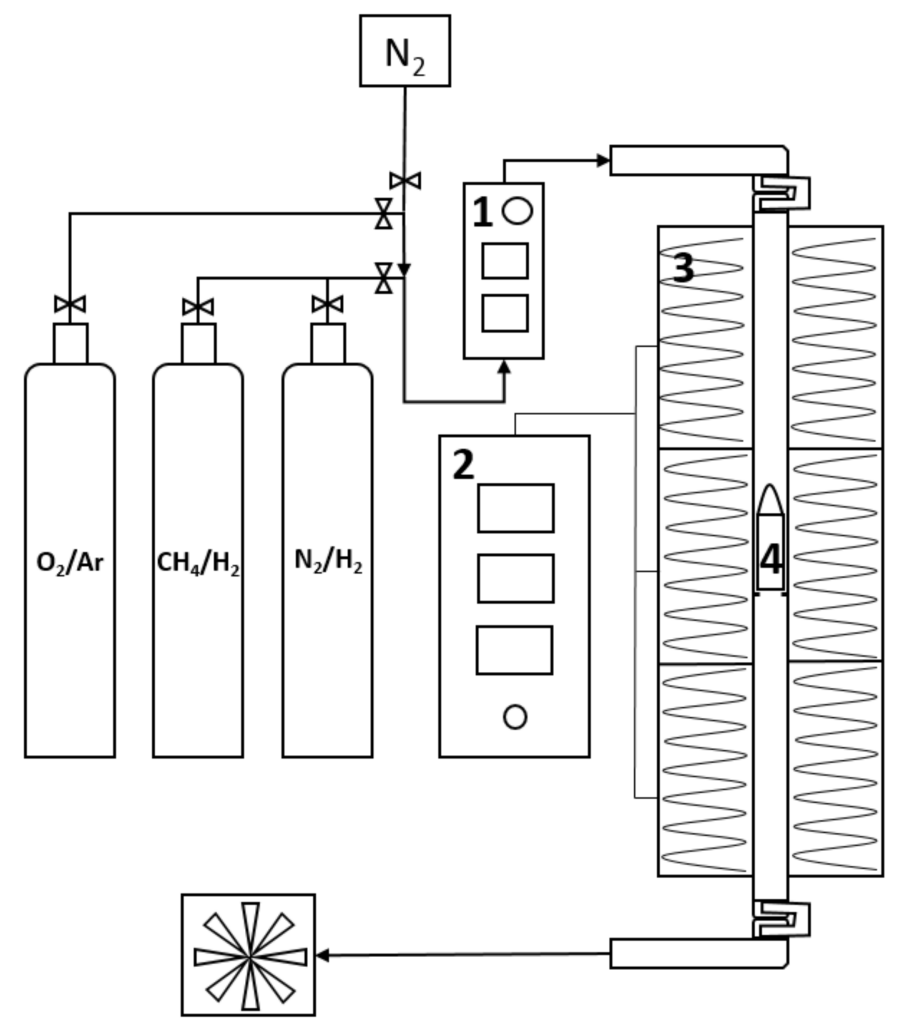

Figure 1. A scheme of the reactor for the preparation of nitrides and carbides, where $1=$ gas flow rate controller, 2 = temperature controller, 3 = triple-zone electric oven, $4=$ quartz cuvette with a sample.

\subsection{Characterisation}

The chemical composition of the supported samples was determined by $\mathrm{X}$-ray fluorescence analysis (XRF) of powder materials using S8 Tiger (Bruker AXS GmbH, Karlsruhe, Germany) with the $\mathrm{Rh}$ cathode. The results were interpreted using the Spectra plus software. The non-supported samples were analyzed by the ICP method using ICP-EOS Agilent 725 (Agilent Technologies Inc., Santa Clara, CA, United States). The carbon and nitrogen content was determined by the elemental analysis of the catalyst powder using Flash2000 Elemental Analyzer (Thermo Fisher Scientific S.p.A., Milan, Italy).

The crystallography of all synthesized material catalysts in powder form was analyzed by X-ray diffraction (XRD) analysis using D8 Advance ECO (Bruker AXS GmbH, Karlsruhe, Germany), applying CuK $\alpha$ radiation $(\lambda=1.5406 \AA)$ with a resolution of $0.02^{\circ}$ and a period of $0.5 \mathrm{~s}$. The patterns were collected in the 2 theta range of $5-70^{\circ}$ and evaluated by using the DIFFRAC.EVA software (Bruker AXS $\mathrm{GmbH}$, Karlsruhe, Germany) with the Powder Diffraction File database (PDF 4+ 2018, International Centre for Diffraction Data).

The textural properties of the samples were determined by $\mathrm{N}_{2}$ physisorption and mercury porosimetry. The specific surface area (BET) was measured by $\mathrm{N}_{2}$ adsorption/desorption at $196{ }^{\circ} \mathrm{C}$ by using Autosorb iQ (Quantachrome Instruments, Boynton Beach, FL, United States). All the samples were dried under vacuum before the analysis in a glass-cell at $200^{\circ} \mathrm{C}$ for $16 \mathrm{~h}$. 
The visual appearance was studied by scanning electron microscope (SEM) JSM-7500F (JEOL Ltd., Tokyo, Japan) with a cold cathode-field emission SEM (parameters of measurements: $1 \mathrm{kV}, \mathrm{GB}$ high mode). Additional images were obtained by using an optical microscope Jenavert (Carl Zeiss Microscopy GmbH, Jena, Germany) equipped with a Canon EOS 1200D camera (CMOS chip 18 Mpx, Canon, Taiwan). Images with different focusing were folded by the QuickPHOTO CAMERA software (PROMICRA, Prague, Czech Republic).

Physical properties and stability of the precursors and samples were studied by thermogravimetric analysis (TGA) using TGA Discovery series (TA Instruments, New Castle, DE, United States) operating in the temperature range of $40-900{ }^{\circ} \mathrm{C}$ (heating $10{ }^{\circ} \mathrm{C} / \mathrm{min}$ ) in the nitrogen flow $(20 \mathrm{~mL} / \mathrm{min}$, Linde 5.0). A Quadrupole mass detector OmniStar GSD320 (Pfeiffer Vacuum GmbH, Wien, Austria) was used for detection of fragments in SCAN mode with $1450 \mathrm{~V}$ voltage of the electron multiplier. Thermal behavior of the samples was analyzed by differential scanning calorimetry (DSC) using Q2000 (TA Instruments, New Castle, DE, United States). Approximately 5-10 mg of a sample was placed into Tzero pierced aluminum pans. An initial temperature was equilibrated at $0{ }^{\circ} \mathrm{C}$, then the samples were cooled down to $-50^{\circ} \mathrm{C}$ at a rate of $10^{\circ} \mathrm{C} / \mathrm{min}$ and held for $1 \mathrm{~min}$. After this, the samples were heated up to $450{ }^{\circ} \mathrm{C}\left(10^{\circ} \mathrm{C} / \mathrm{min}\right)$.

\section{Results and Discussion}

\subsection{Precursors}

Initially, before the synthesis, all of the precursors were characterized by several analytical methods. As seen from Figure 2, X-ray patterns of the precursor structures differ. In the sample HMT+AHM-M (8:1) produced by mechanical mixing of HMT and AHM, the presence of diffraction lines appropriated to AHM and HMT was observed. However, the line corresponding to the formation of the HMT-AHM complex was also present in the sample.

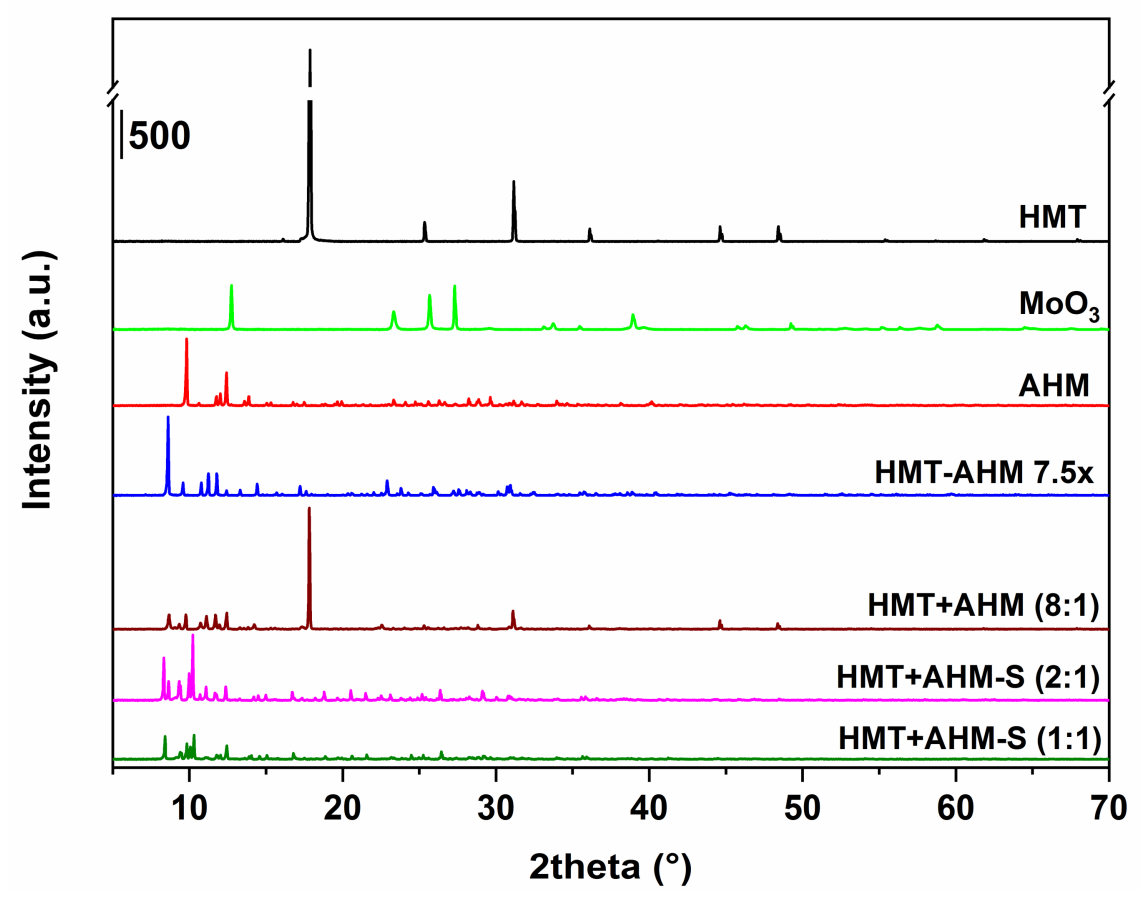

Figure 2. X-ray diffraction patterns of the synthesized precursors and the starting feedstock.

The precursor complexes, synthesized using HMT+AHM-S, were similar, but not completely the same to those reported by Afanasiev. The $\mathrm{MoO}_{3}$ sample had typical diffraction patterns corresponding to molybdenum trioxide (molybdite). 
The influence of the HMT excess on the HMT-AHM complex prepared by the Afanasiev method was investigated by varying the molar ratio of HMT:AHM in the sequence of 15:1 (sample HMT-AHM $7.5 \times$ ), 10:1, and 20:1 (samples HMT-AHM 5× and 10×). The TGA results (Figure 3 ) show that the forming complexes were absolutely identical. Their similarity was confirmed by the same decomposition in terms of mass depletion of the final residues and decomposition rates at the corresponding temperatures.

a)

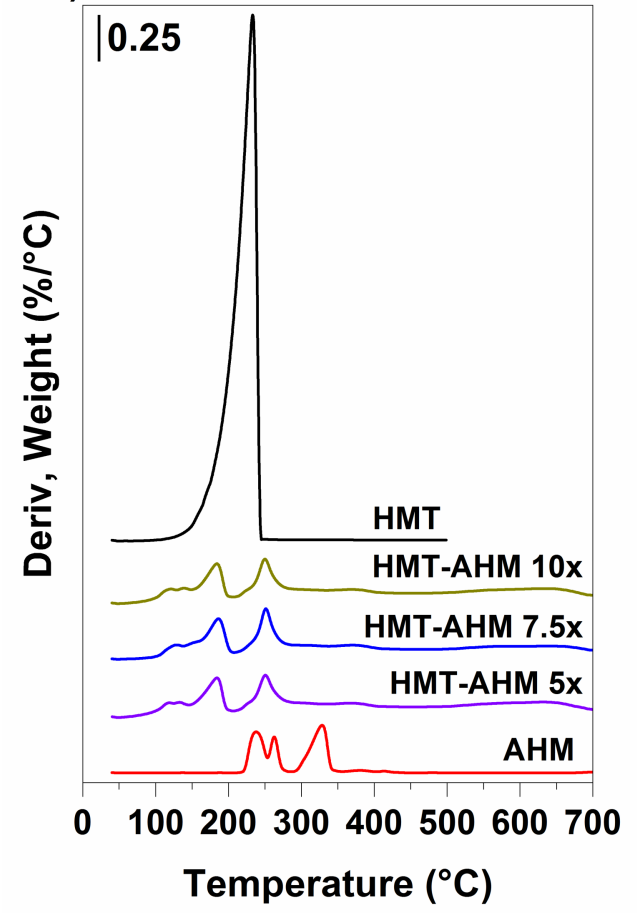

b)

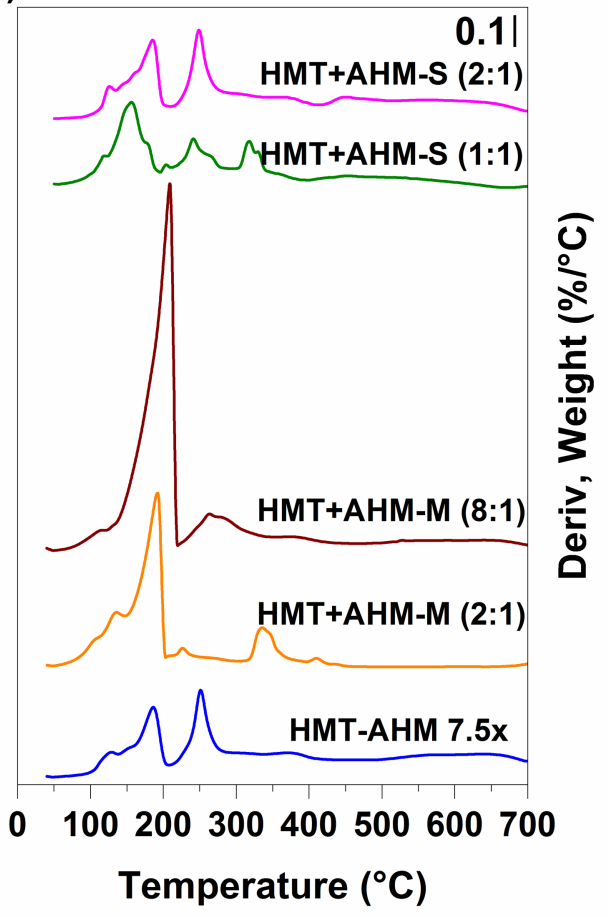

Figure 3. Thermogravimetric analysis of the synthesised precursors (a) and the starting feedstock (b).

Decomposition of other precursors differed from the HMT-AHM 7.5 $\times$ sample. Thus, in the case of HMT+AHM-M (2:1) and HMT+AHM-M (8:1), a conspicuous signal at $200{ }^{\circ} \mathrm{C}$ inherent to HMT decomposition was observed. The crystallization of the HMT and AHM ammonia solution with a molar ratio of 1:1 in the sample HMT+AHM-S (1:1) led to the formation of large transparent crystals that decomposed differently than when only tiny crystals were formed in the sample HMT+AHM-S (2:1). In spite of the fact that the TGA curves of the latter and HMT-AHM 7.5 $\times$ went through the same trajectory and were very similar, a slight difference in their structures was noticeable.

TGA decompositions of AHM and HMT-AHM were determined using a mass spectrometer. Using the literature data $[47,48]$, it was possible to determine the individual decomposition steps. It was found that thermal destruction at temperatures from 100 to $190{ }^{\circ} \mathrm{C}$ resulted in a simultaneous release of $\mathrm{H}_{2} \mathrm{O}$ and $\mathrm{NH}_{3}$, giving transition polymolybdate phases. At the same time, fragments corresponding to $\mathrm{NO}, \mathrm{N}_{2} \mathrm{O}, \mathrm{O}_{2}$, and $\mathrm{N}_{2}$ were also observed, which may have been caused by the presence of air in the thermogravimetric furnace, which was not hermetically sealed. The HMT-AHM complex differed by the signal of $\mathrm{CO}_{2}$ detected in the range of $190-275^{\circ} \mathrm{C}$, which further gradually released up to $700{ }^{\circ} \mathrm{C}$.

DSC results displayed in Figure 4 show that the HMT-AHM complexes prepared with different HMT excesses (HMT-AHM 5×, 7.5× and $10 \times$ ), as in TGA, had identical profiles. In comparison with the samples HMT+AHM-M (2:1) and HMT+AHM-M (8:1), some differences to the HMT-AHM complex in the DSC signals were recorded. 
a)

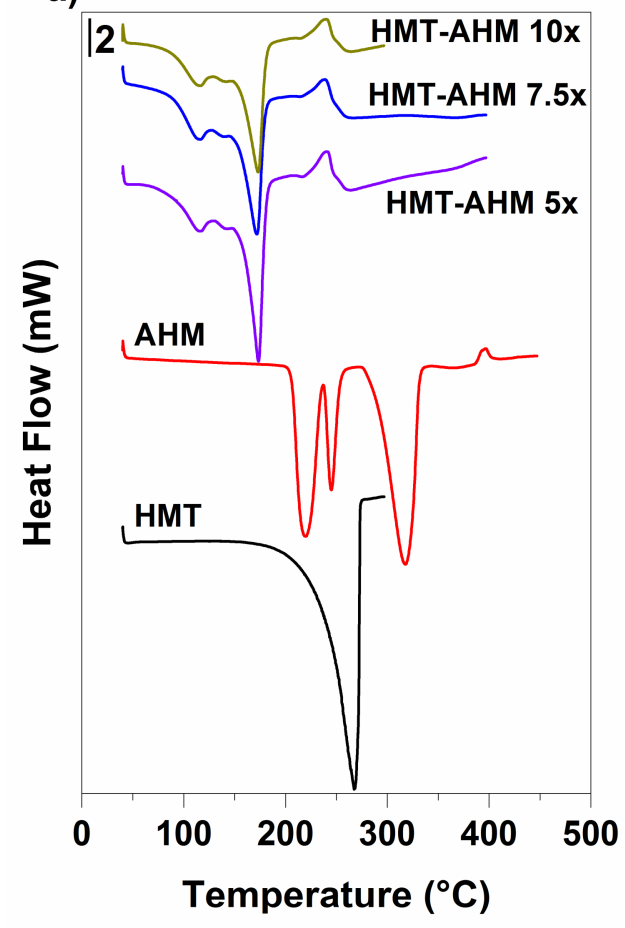

b)

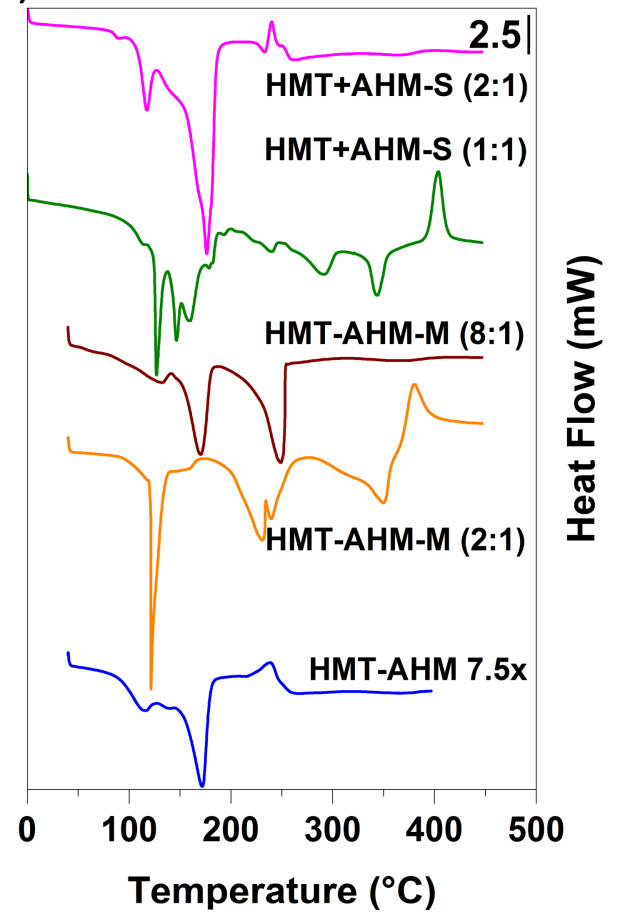

Figure 4. Thermal behavior of the synthesised precursors (a) and the starting feedstock (b) provided by differential scanning calorimetry (DSC).

HMT+AHM-M (2:1) had a sharp endothermic peak, which occurred in the temperature range of $110-130{ }^{\circ} \mathrm{C}$, and the subsequent endothermic peaks at $250-350{ }^{\circ} \mathrm{C}$ correspond to AHM. The change in the molar ratio of HMT:AHM in HMT+AHM-M (8:1) sample also changed the DSC curve. Only two distinct peaks were observable on the record: the first endothermic peak at $170.51^{\circ} \mathrm{C}$ corresponded to AHM decomposition and the second one at $248.73{ }^{\circ} \mathrm{C}$ to HMT sublimation.

According to the DSC records, the complexes obtained by crystallization of the HMT and AHM ammonia solutions differed among themselves and also in comparison with the HMT-AHM complex prepared by the Afanasiev method. Both HMT+AHM-S (1:1) and HMT+AHM-S (2:1), as well as HMT+AHM-M (2:1) complexes, were characterized by the endothermic peak around $120^{\circ} \mathrm{C}$, which was probably related to the sudden formation of another type of a complex. Despite the fact that the HMT-AHM complex had the same peak, but not quite at intensely, we can conclude that the complex is very similar, but not exactly identical to HMT+AHM-S (2:1). This difference also affected the final structure of molybdenum nitrides and carbides.

SEM results (Figure 5) show that the surface morphology of the HMT+AHM-S (2:1) sample was more crystallized than the HMT-AHM complex. The $\mathrm{MoO}_{3}$ sample has small molybdite crystals produced by thermal decomposition of AHM. 

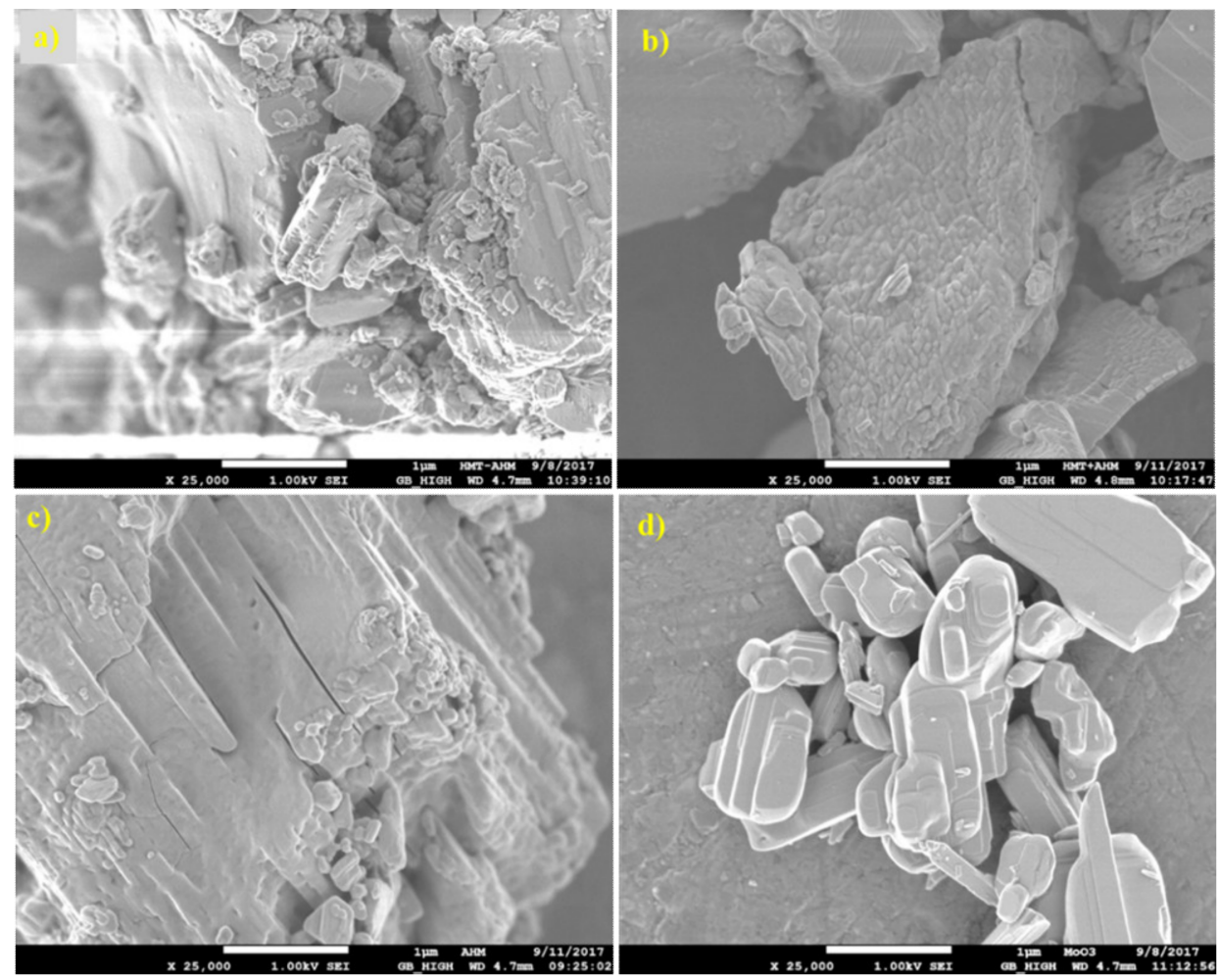

Figure 5. Scanning electron microscopic (SEM) micrographs of the synthesised precursors (a) HMT-AHM 7.5 $\times$ and (b) HMT-AHM-S (2:1), and the starting feedstock (c) AHM and (d) $\mathrm{MoO}_{3}$.

\subsection{Non-Supported MoCx}

Non-supported (bulk) molybdenum carbides were synthesised using $20 \mathrm{vol} \% \mathrm{CH}_{4}$ in $\mathrm{H}_{2}$ with a flowrate of $75 \mathrm{~cm}^{3} / \mathrm{min}$. All the prepared samples showed a high carbon content (Table 1), indicating their complete conversion to carbides. Only the sample where the AHM precursor was used and the reaction temperature was $600{ }^{\circ} \mathrm{C}$ contained much less carbon. This was confirmed by X-ray diffraction, where the majority phase was monoclinic $\mathrm{MoO}_{2}$ and at the same time a minor orthorhombic modification of $\alpha-\mathrm{Mo}_{2} \mathrm{C}$ occurred. The fractions of the carbide phases and their crystallite sizes are shown in Table 1. As seen from the diffraction patterns of the samples synthesised from the AHM and HMT-AHM precursors at different temperatures (Figure 6), both of them provided a mixture of $\alpha$ - and $\beta-\mathrm{Mo}_{2} \mathrm{C}$ in the ratio of about $2: 1$ at $700{ }^{\circ} \mathrm{C}$ and only $\alpha-\mathrm{Mo}_{2} \mathrm{C}$ at $800{ }^{\circ} \mathrm{C}$. There was no complete conversion to any carbide phase at low temperatures for AHM (Figure 6a), while HMT-AHM (Figure $6 \mathrm{~b}$ ) gave hexagonal $\beta-\mathrm{Mo}_{2} \mathrm{C}$ already at $600{ }^{\circ} \mathrm{C}$. Other precursors provided a pure $\alpha-\mathrm{Mo}_{2} \mathrm{C}$ phase only at $700{ }^{\circ} \mathrm{C}$ (Figure 7).

Table 1. Physicochemical properties of the prepared molybdenum carbides.

\begin{tabular}{|c|c|c|c|c|c|c|}
\hline \multirow[t]{2}{*}{ Sample } & \multirow{2}{*}{$\begin{array}{c}S_{\text {BET }} \\
\left(\mathrm{m}^{2} / g\right)\end{array}$} & \multicolumn{2}{|c|}{$\begin{array}{c}\text { Elemental Analysis } \\
(\mathbf{w t} \%)\end{array}$} & \multicolumn{3}{|c|}{$\begin{array}{l}\text { Content of Crystalline Phase } \\
\text { (\%)/Crystallite Size D (nm) }\end{array}$} \\
\hline & & C & $\mathbf{N}$ & $\beta-\mathrm{Mo}_{2} \mathrm{C}$ & $\alpha-\mathrm{Mo}_{2} \mathrm{C}$ & $\mathrm{MoO}_{2}$ \\
\hline AHM-600 & 3.9 & 1.64 & $<0.05$ & - & $12 / 18.2$ & $88 /-$ \\
\hline AHM-700 & 7.4 & 5.41 & $<0.05$ & $34 /-$ & $66 / 14.3$ & - \\
\hline AHM-800 & 5.3 & 6.32 & $<0.05$ & - & $100 / 40.2$ & - \\
\hline HMT-AHM-600 * & 19.4 & 5.49 & $<0.05$ & $100 / 4.9$ & - & - \\
\hline HMT-AHM-700 * & 25.3 & 6.52 & $<0.05$ & $32 /-$ & $68 / 14.6$ & - \\
\hline HMT-AHM-800 * & 14.1 & 8.34 & $<0.05$ & - & $100 / 21.3$ & - \\
\hline HMT+AHM-S $(1: 1)^{* *}$ & 16.2 & 4.96 & $<0.05$ & - & $100 / 18.4$ & - \\
\hline HMT+AHM-S $(2: 1)^{* *}$ & 51.8 & 4.43 & $<0.05$ & - & $100 / 15.1$ & - \\
\hline
\end{tabular}


Table 1. Cont.

\begin{tabular}{|c|c|c|c|c|c|c|}
\hline \multirow[t]{2}{*}{ Sample } & \multirow{2}{*}{$\begin{array}{l}S_{\text {BET }} \\
\left(\mathrm{m}^{2} / g\right)\end{array}$} & \multicolumn{2}{|c|}{$\begin{array}{l}\text { Elemental Analysis } \\
\text { (wt } \%)\end{array}$} & \multicolumn{3}{|c|}{$\begin{array}{l}\text { Content of Crystalline Phase } \\
(\%) / C r y s t a l l i t e \text { Size D (nm) }\end{array}$} \\
\hline & & $\mathrm{C}$ & $\mathbf{N}$ & $\beta-\mathrm{Mo}_{2} \mathrm{C}$ & $\alpha-\mathrm{Mo}_{2} \mathrm{C}$ & $\mathrm{MoO}_{2}$ \\
\hline HMT+AHM-M (2:1) ${ }^{* *}$ & 8.7 & 5.66 & $<0.05$ & - & $100 / 21.3$ & - \\
\hline HMT+AHM-M $(8: 1)^{* *}$ & 18.3 & 6.27 & $<0.05$ & - & $100 / 19.8$ & - \\
\hline $\mathrm{MoO}_{3}$ ** & 0.0 & 5.81 & $<0.05$ & - & $100 / 18.5$ & - \\
\hline
\end{tabular}

${ }^{*}$ HMT-AHM $7.5 \times$ precursor, ${ }^{* *}$ preparation at $700{ }^{\circ} \mathrm{C}$.

a)

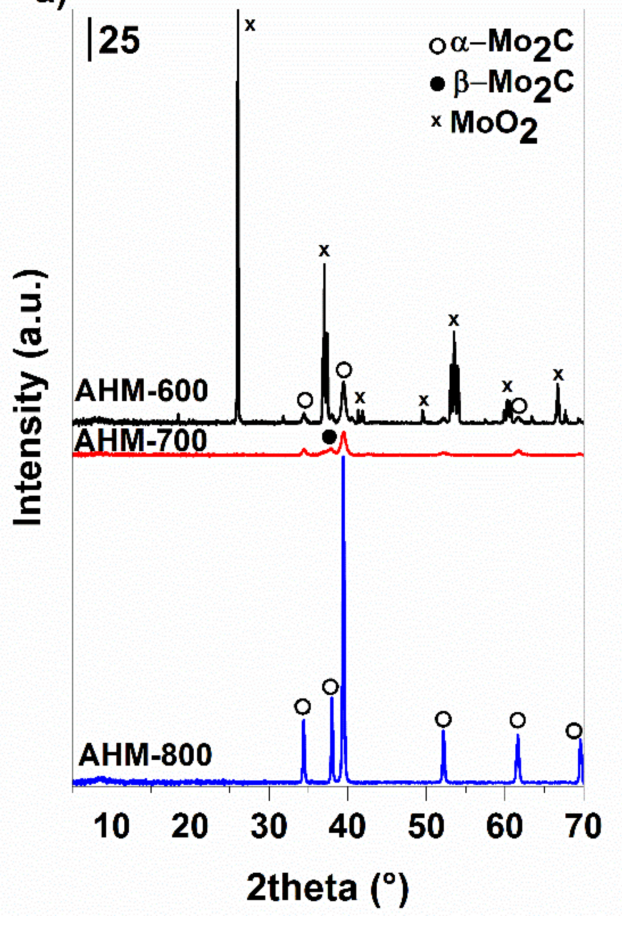

b)

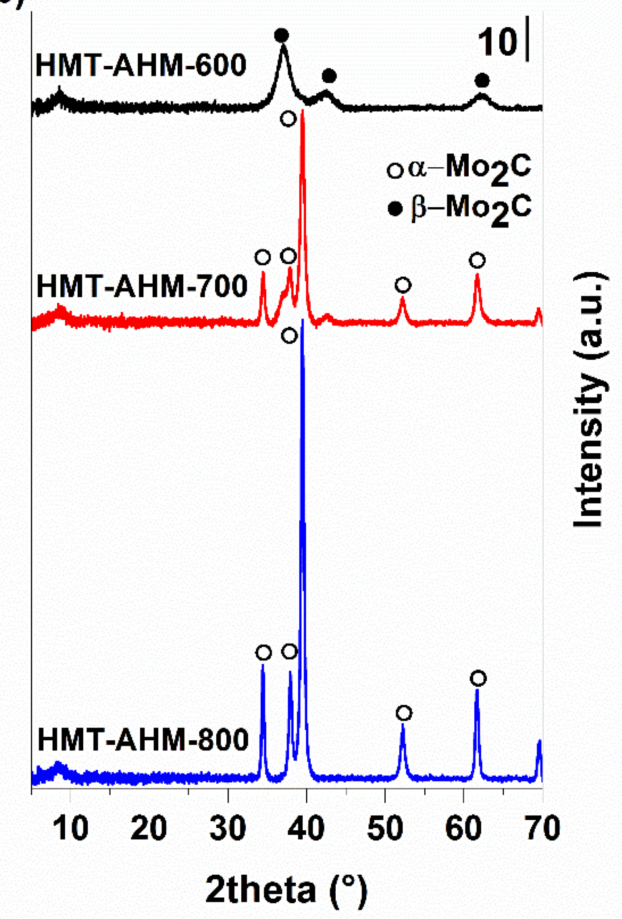

Figure 6. X-ray diffraction patterns of the molybdenum carbides prepared from AHM (a) and HMT-AHM (b) at $600-800{ }^{\circ} \mathrm{C}$.

The prepared carbides showed a relatively wide range of specific surface area values (Table 1 ). The samples synthesized from HMT+AHM-S (2:1) had an area two times higher than when HMT-AHM was used. The specific surface areas of the other samples were very small or even equal to zero, though they all contained the carbide phase.

The crystallites sizes (Table 1 ) were relatively equal. These values were mostly in the range from 14.3 to $21.3 \mathrm{~nm}$ for the $\alpha-\mathrm{Mo}_{2} \mathrm{C}$ phase. The exception was AHM-800, the crystallite size of wich was $40.2 \mathrm{~nm}$. The size of the $\beta-\mathrm{Mo}_{2} \mathrm{C}$ crystalline phase was possible to determine only for the sample HMT-AHM-600, where this phase appears separately. The size of $\beta-\mathrm{Mo}_{2} \mathrm{C}$ crystallites in this sample was $4.9 \mathrm{~nm}$. In the case of AHM-700 and HMT-AHM-700, crystallite sizes could not be measured due to the overlap of corresponding diffraction lines. The crystallites sizes were calculated from the reflection of $39.5^{\circ} 2$ theta for $\alpha-\mathrm{Mo}_{2} \mathrm{C}$ and $37.1^{\circ} 2$ theta for $\beta-\mathrm{Mo}_{2} \mathrm{C}$.

The structure of the prepared non-supported molybdenum carbides was analysed using scanning electron and optical microscopes. The samples synthesised from the HMT-AHM and HMT+AHM-S (2:1) complexes showed a well-crystallized structure, while the microcrystalline structure was peculiar to the samples obtained from AHM (Figure 8). Evaluation of the structure using SEM revealed a distinctive spongy (foam) structure of the prepared samples (Figure 9). 


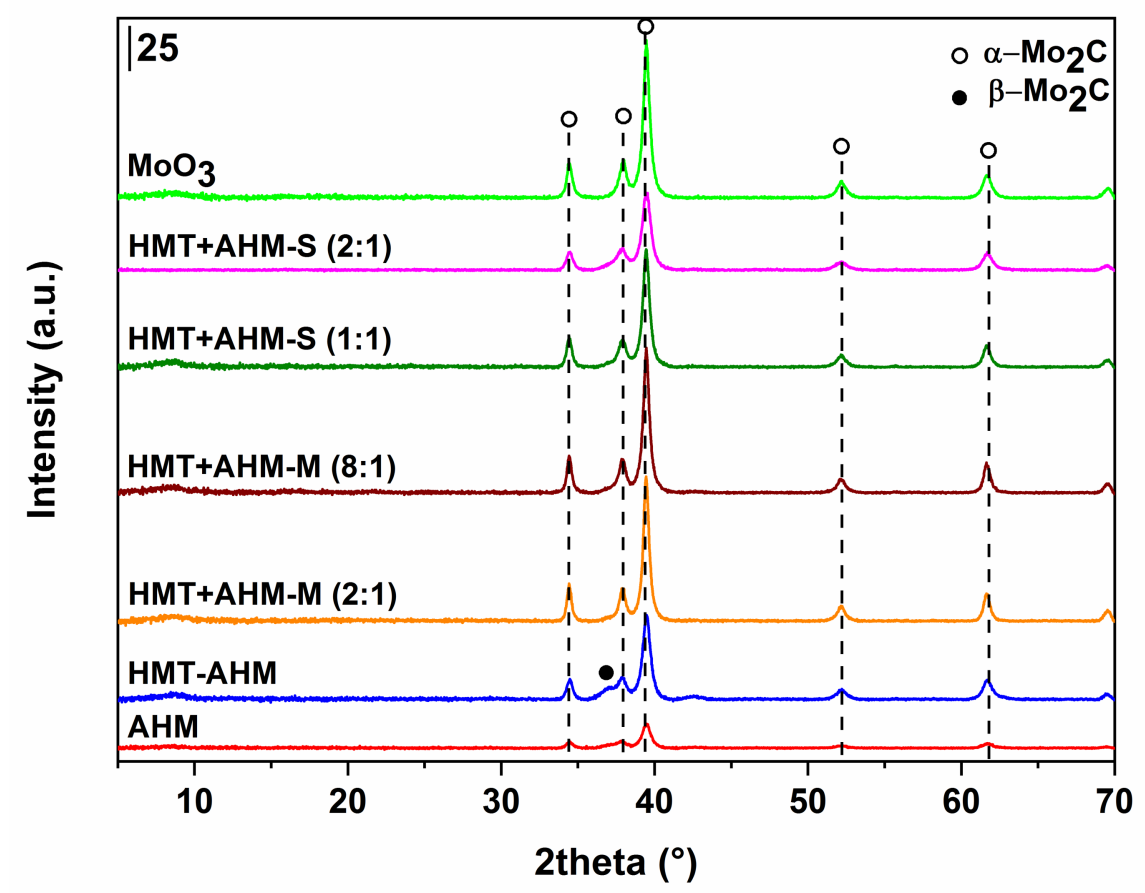

Figure 7. X-ray diffraction patterns of the molybdenum carbides prepared from different precursors at $700{ }^{\circ} \mathrm{C}$.

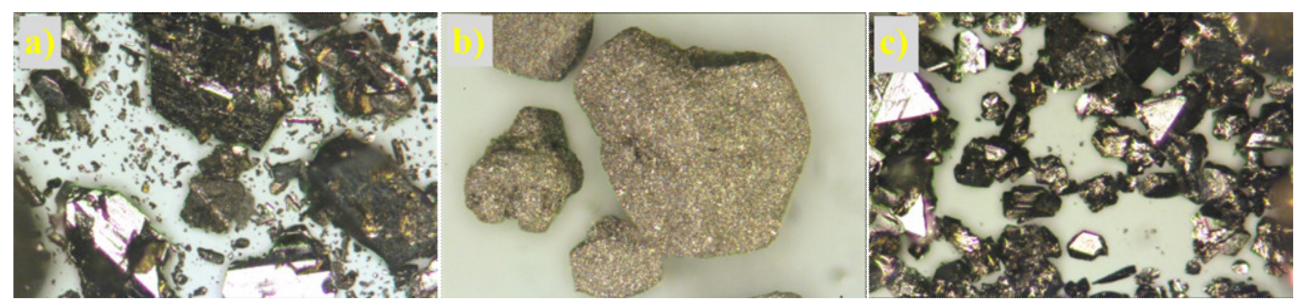

Figure 8. Microscope images of molybdenum carbides at $25 \times$ magnification obtained from (a) HMT-AHM-700, (b) AHM-800, (c) HMT+AHM-S (2:1)-700.
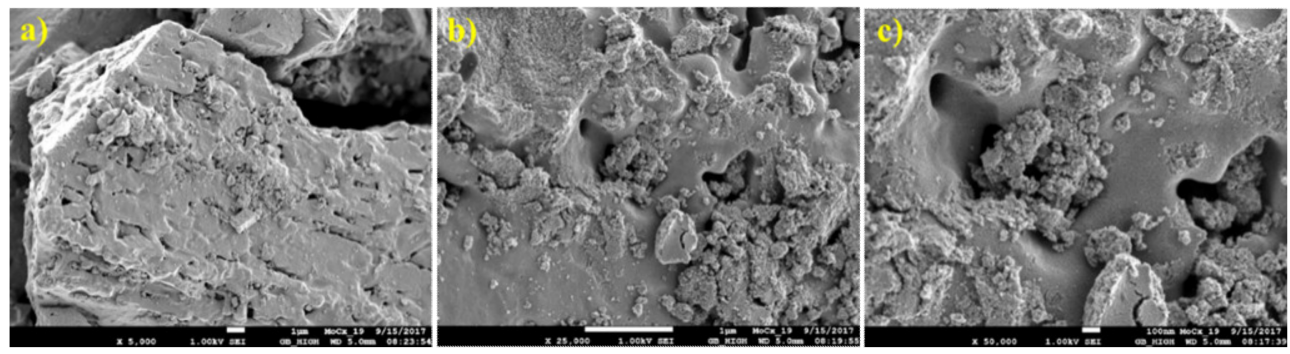

Figure 9. SEM images of molybdenum carbides synthesised from HMT-AHM-600 at magnifications of (a) $5000 \times$, (b) $25,000 \times$, and (c) $100,000 \times$.

\subsection{Non-Supported MoNx}

All the non-supported (bulk) molybdenum nitrides were synthesised using the same conditions as for carbides. A mixture of $20 \mathrm{vol} \% \mathrm{H}_{2}$ in $\mathrm{N}_{2}$ was used as a working gas. The specific surface area of the prepared materials and the nitrogen content were very dependent on the content and type of the nitride phase (Table 2). The maximum was $29 \mathrm{~m}^{2} / \mathrm{g}$ for the sample prepared from HMT+AHM-M (8:1), followed by HMT-AHM-700. Nitrogen content (Table 2) clearly showed that the nitride phase was produced only under certain conditions, while carbides were formed in the case of each precursor 
and temperature. A distinctive feature in nitride samples was the presence of carbon, indicating the presence of the carbide phase. The highest carbon and nitrogen were typical for the samples produced from HMT-AHM $\left(700,800{ }^{\circ} \mathrm{C}\right)$ and HMT+AHM-S (2:1) precursors. The presence of carbon can be explained by the incomplete decomposition of HMT, which was present in the structure of the used precursor complex. The minor phase was confirmed as orthorhombic carbide phase $\alpha-\mathrm{Mo}_{2} \mathrm{C}$, based on the XRD data.

Table 2. Physicochemical properties of the prepared molybdenum nitrides.

\begin{tabular}{|c|c|c|c|c|c|c|c|c|}
\hline \multirow[t]{2}{*}{ Sample } & \multirow{2}{*}{$\begin{array}{l}S_{\text {BET }} \\
\left(\mathrm{m}^{2} / \mathrm{g}\right)\end{array}$} & \multicolumn{2}{|c|}{$\begin{array}{c}\text { Elemental } \\
\text { Analysis (wt\%) }\end{array}$} & \multicolumn{5}{|c|}{ Content of Crystalline Phase (\%)/Crystallite Size D (nm) } \\
\hline & & $\mathrm{C}$ & $\mathbf{N}$ & $\beta-\mathrm{Mo}_{2} \mathrm{~N}$ & $\gamma-\mathrm{Mo}_{2} \mathrm{~N}$ & $\mathrm{Mo}_{3} \mathrm{~N}_{2}$ & Mo & $\mathrm{MoO}_{2}$ \\
\hline AHM-700 & 0.0 & $<0.05$ & 0.37 & $19 / 27.4$ & - & - & $36 /-$ & $45 /-$ \\
\hline AHM-800 & 0.0 & 0.05 & $<0.05$ & - & - & - & $57 /-$ & $43 /-$ \\
\hline AHM-900 & 0.1 & $<0.05$ & $<0.05$ & - & - & - & $69 /-$ & $31 /-$ \\
\hline HMT-AHM-700 * & 25.0 & 0.45 & 5.68 & - & $100 / 13.8$ & - & - & - \\
\hline HMT-AHM- 800 * & 11.5 & $<0.05$ & 5.96 & $100 / 26.0$ & - & - & - & - \\
\hline HMT-AHM-900 * & 0.0 & $<0.05$ & $<0.05$ & - & - & - & $100 /-$ & - \\
\hline HMT+AHM-S (1:1) ** & 16.2 & 0.15 & 2.44 & $14 / 18.3$ & - & - & - & $86 /-$ \\
\hline HMT+AHM-S (2:1) ** & 13.2 & 0.54 & 5.95 & - & - & $100 / 11.7$ & - & - \\
\hline HMT+AHM-M (2:1) ** & 12.2 & 0.15 & 2.32 & 78/17.6 & - & - & $1 /-$ & $21 /-$ \\
\hline HMT+AHM-M $(8: 1) * *$ & 29.0 & 0.09 & 0.97 & $76 / 17.5$ & - & - & - & $24 /-$ \\
\hline $\mathrm{MoO}_{3} * *$ & 0.3 & $<0.05$ & $<0.05$ & - & - & - & $2 /-$ & 98/- \\
\hline
\end{tabular}

${ }^{*}$ HMT-AHM $7.5 \times$ precursor, ${ }^{* *}$ preparation at $700{ }^{\circ} \mathrm{C}$.

The use of the AHM precursor (Figure 10a) did not lead to the formation of molybdenum nitride; only traces of tetragonal $\beta-\mathrm{Mo}_{2} \mathrm{~N}$ modification, the cubic phase of metallic molybdenum, and monoclinic $\mathrm{MoO}_{2}$ started to occur at $700{ }^{\circ} \mathrm{C}$. Higher temperatures resulted in metal molybdenum and $\mathrm{MoO}_{2}$. Nitridation of HMT-AHM (Figure 10b) gave a cubic modification of $\gamma-\mathrm{Mo}_{2} \mathrm{~N}$ accompanied by a small $\alpha-\mathrm{Mo}_{2} \mathrm{C}$ fraction at $700{ }^{\circ} \mathrm{C}$. Formation of $\beta-\mathrm{Mo}_{2} \mathrm{~N}$ was observed at $800{ }^{\circ} \mathrm{C}$ and only metallic molybdenum was formed at $900{ }^{\circ} \mathrm{C}$. The sample prepared from the HMT+AHM-S (2:1) precursor at $700{ }^{\circ} \mathrm{C}$ was cubic $\mathrm{Mo}_{3} \mathrm{~N}_{2}$ with a small amount of $\alpha-\mathrm{Mo}_{2} \mathrm{C}$. The other precursors examined by XRD (Figure 11) produced a mixture of $\beta-\mathrm{Mo}_{2} \mathrm{~N}$ with $\mathrm{MoO}_{2}$, in the case of the precursor HMT+AHM-S (1:1) (the mixture with a small proportion of metal molybdenum). An exception was for the previously mentioned HMT+AHM-S (2:1), where cubic $\mathrm{Mo}_{3} \mathrm{~N}_{2}$ was formed with a small proportion of $\alpha-\mathrm{Mo}_{2} \mathrm{C}$. The $\mathrm{MoO}_{3}$ precursor was only partially reduced to $\mathrm{MoO}_{2}$ and produced a very small proportion of metallic molybdenum.

The crystallite sizes of the nitride phases are shown in Table 2. The biggest crystallite size was related to the $\beta-\mathrm{Mo}_{2} \mathrm{~N}$ phase and determined at $37.4^{\circ} 2$ theta. The value was in two ranges of about 18 and $27 \mathrm{~nm}$. Crystallite sizes of other presented phases $\gamma-\mathrm{Mo}_{2} \mathrm{~N}(13.8 \mathrm{~nm})$ and $\beta-\mathrm{Mo}_{2} \mathrm{~N}(11.7 \mathrm{~nm})$ were calculated at $37.5^{\circ}$ and $37.7^{\circ} 2$ theta, respectively.

Optical and electron micrographs did not show any noticeable difference between molybdenum carbide and nitride samples (Figures 12 and 13). Nitridation of HMT-AHM and HMT+AHM-S (2:1) precursor complexes also resulted in a very crystalline product, while HMT+AHM-M produced a microcrystalline product (Figure 12). The sponge structure was also typical for these materials (Figure 13), but was more distinct and produced labyrinths in comparison to carbides, where relatively small isolated circular pores were observed. When the HMT+AHM-S (1:1) precursor was used, a mixture of two different phases was observed (Figure 14a). A crystalline phase was composed of tugarinovite $\left(\mathrm{MoO}_{2}\right)$ and sponge phases consisted of $\beta-\mathrm{Mo}_{2} \mathrm{~N}$ phases. The same crystalline phase was observed when using the $\mathrm{MoO}_{3}$ precursor (Figure 14b). 


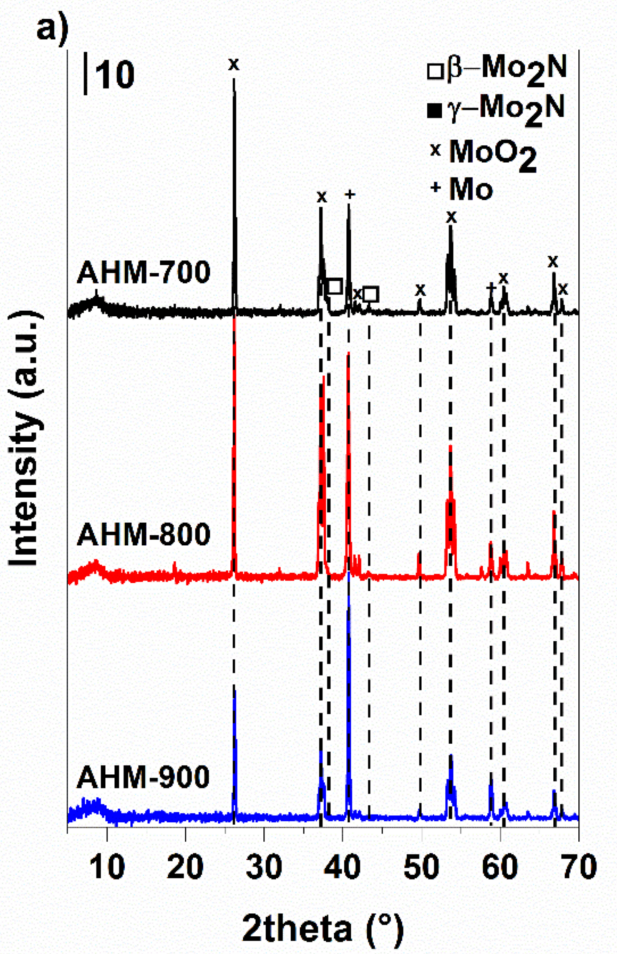

b)

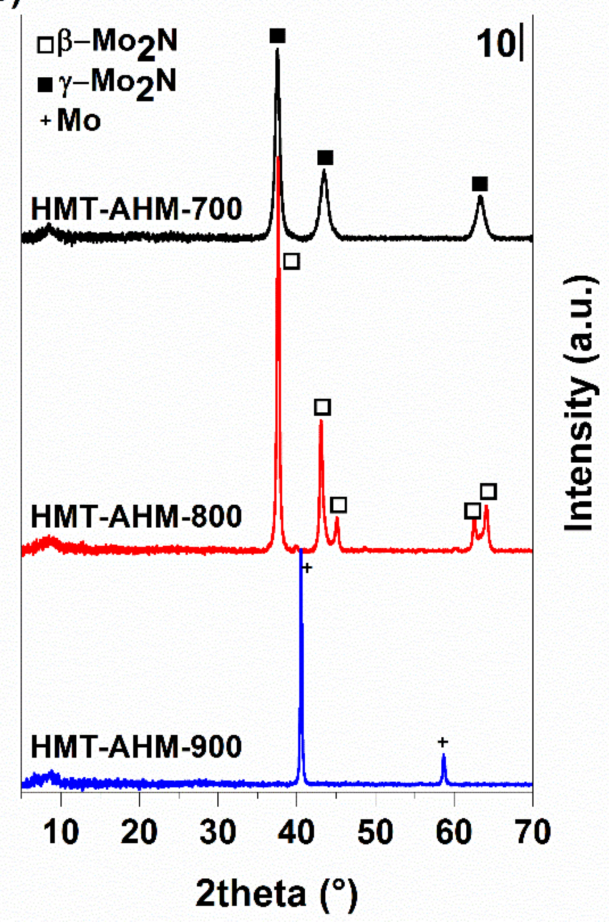

Figure 10. X-ray diffraction patterns of the molybdenum nitrides prepared from AHM (a) and HMT-AHM (b) at $700-900{ }^{\circ} \mathrm{C}$.

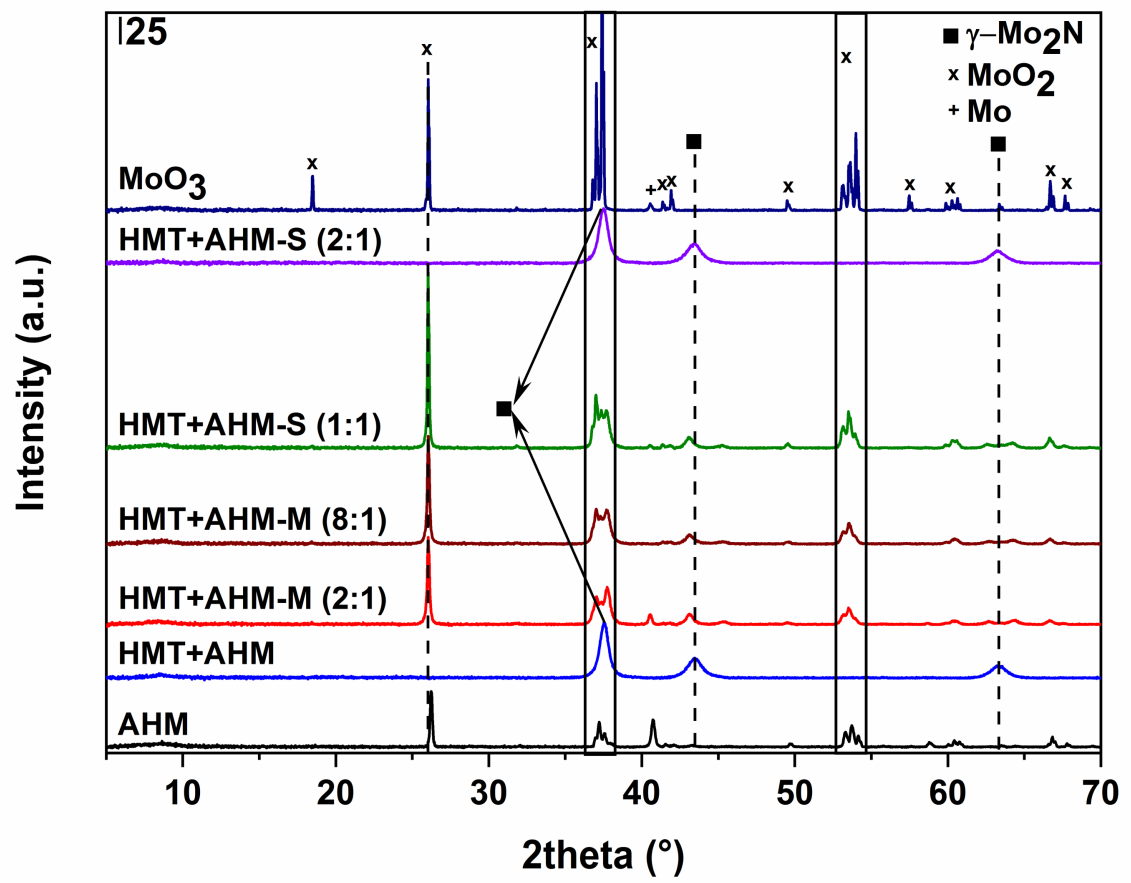

Figure 11. X-ray diffraction patterns of the molybdenum nitrides prepared at $700{ }^{\circ} \mathrm{C}$. 


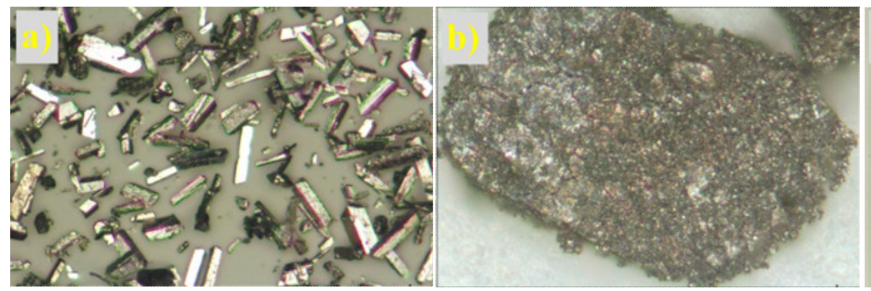

Figure 12. Microphotographs of the samples at $25 \times$ magnification: (b) HMT+AHM-M (8:1), and (c) HMT+AHM-S (2:1).
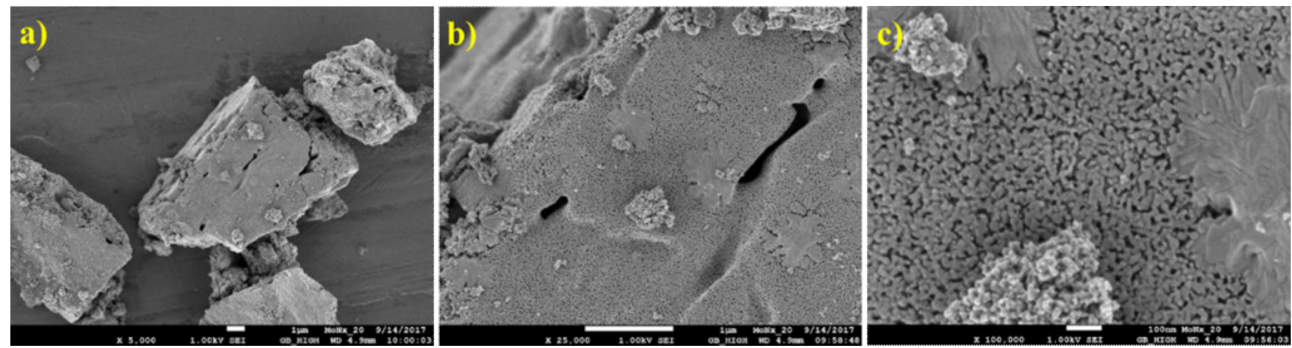

Figure 13. SEM images of HMT-AHM-700 in different magnifications: (a) $5000 \times$, (b) $25,000 \times$, and (c) $100,000 \times$.
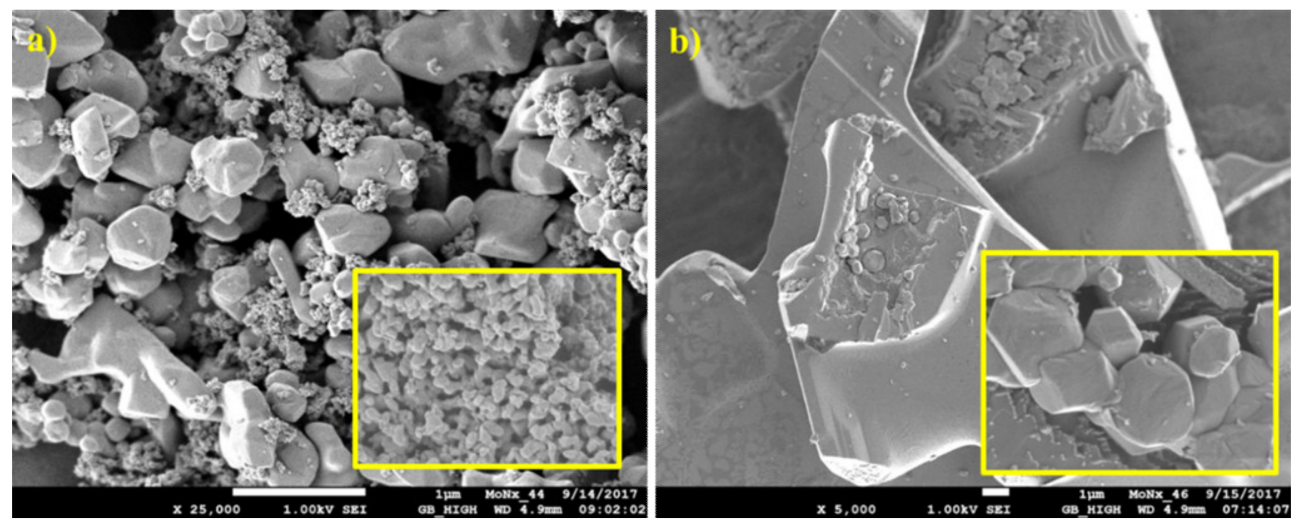

Figure 14. SEM images of (a) HMT+AHM-S (1:1) and (b) MoO3 prepared at $700{ }^{\circ} \mathrm{C}$ (magnifications of $25,000 \times$ and $100,000 \times)$.

The obtained data show that the investigated precursors had a high influence on the physico-chemical properties of the prepared materials. It was found that the carbide phase was easier to obtain than the pure nitride phase, which was observed only when using the HMT-AHM precursor at $800{ }^{\circ} \mathrm{C}$, while the carbide phase was present at a temperature above $600{ }^{\circ} \mathrm{C}$ for all used precursors except AHM, giving mainly $\mathrm{MoO}_{2}$. The summarized scheme of the carburization/nitridation process of HMT-AHM is presented on Figure 15.

Another fact, confirming that the carbides were produced more easily (compare to nitrides), was evidenced by the presence of $\alpha-\mathrm{Mo}_{2} \mathrm{C}$ formed from HMT-AHM and HMT+AHM-S (2:1) at $700{ }^{\circ} \mathrm{C}$ as a concomitant phase. Basing on these results, we can conclude that HMT-AHM and HMT+AHM-S (2:1) were the most effective precursors of molybdenum carbides and nitrides synthesis. Even though they were very similar, they were not identical materials. 


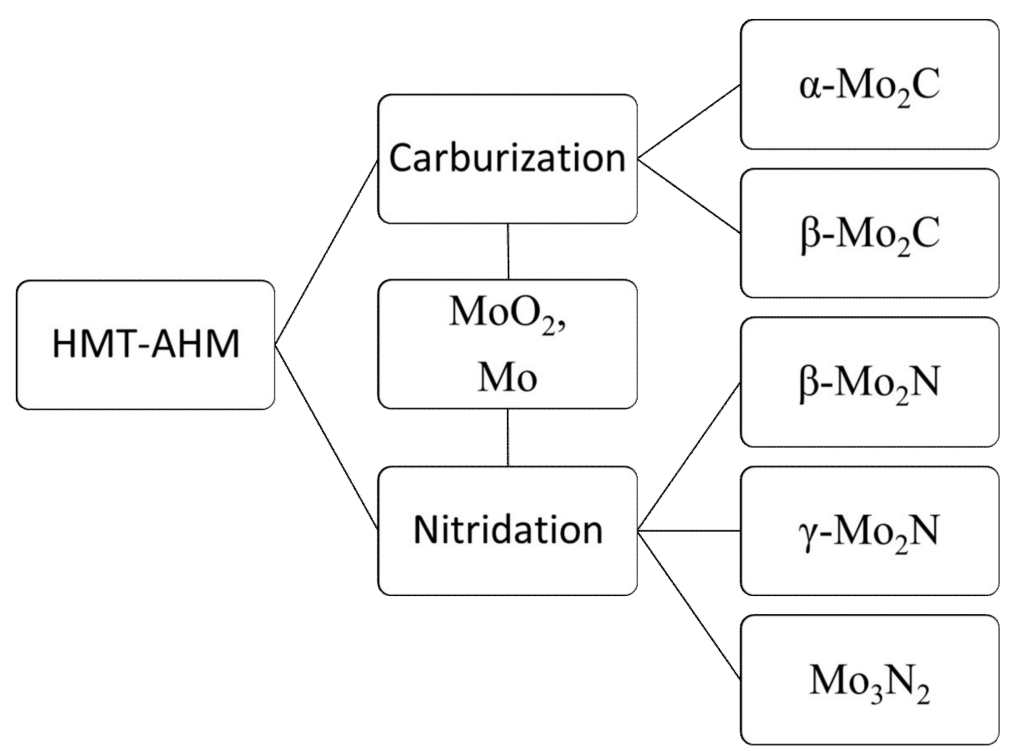

Figure 15. A general scheme of the carburization/nitridation process of HMT-AHM.

\subsection{Supported Samples}

Basing on the synthesis of the non-supported molybdenum carbides and nitrides, the HMT-AHM precursor was chosen to prepare supported samples. $\mathrm{HMT}+\mathrm{AHM}-\mathrm{S}(2: 1)$ on $\mathrm{Al}_{2} \mathrm{O}_{3}{ }^{\#}$ was used for the comparative study. The preparation temperature was $700{ }^{\circ} \mathrm{C}$ as a compromise between the formation of the desired phase and the avoidance of structural changes in the supports. The samples exhibited high molybdenum contents ranging from 22.1 to $38.4 \mathrm{wt} \%$ (Table 3). As a consequence, the high content of the carbide $\left(\mathrm{MoC}_{\mathrm{x}}\right)$ or nitride $\left(\mathrm{MoN}_{\mathrm{x}}\right)$ phases decreased the initial specific surface area of the SBA-15 and BEA supports.

Table 3. Chemical composition and specific surface areas of the supported samples.

\begin{tabular}{|c|c|c|c|c|c|c|c|c|c|c|c|c|c|}
\hline \multirow[t]{2}{*}{ Support } & \multirow{2}{*}{$\begin{array}{c}\text { Initial } \\
\mathrm{S}_{\text {BET }}\left(\mathrm{m}^{2} / \mathrm{g}\right)\end{array}$} & \multicolumn{5}{|c|}{$\begin{array}{r}\text { Supported Nitrides } \\
\text { Chemical Composition (wt } \%)\end{array}$} & \multirow{2}{*}{$\begin{array}{l}\mathrm{S}_{\mathrm{BET}} \\
\left(\mathrm{m}^{2} / \mathrm{g}\right)\end{array}$} & \multicolumn{5}{|c|}{$\begin{array}{c}\text { Supported Carbides } \\
\text { Chemical Composition (wt } \%)\end{array}$} & \multirow{2}{*}{$\begin{array}{l}\mathrm{S}_{\mathrm{BET}} \\
\left(\mathrm{m}^{2} / \mathrm{g}\right)\end{array}$} \\
\hline & & Mo & $X^{*}$ & $\mathrm{Si}$ & C & $\mathbf{N}$ & & Mo & $X^{*}$ & $\mathrm{Si}$ & C & $\mathbf{N}$ & \\
\hline $\mathrm{Al}_{2} \mathrm{O}_{3}$ & \multirow{2}{*}{192} & 22.5 & 33.9 & 0.0 & 0.08 & 1.03 & 123.6 & 22.1 & 38.3 & 0.0 & 1.46 & $<0.05$ & 118.8 \\
\hline $\mathrm{Al}_{2} \mathrm{O}_{3} \#$ & & 23.2 & 38.4 & 0.0 & 0.19 & 0.86 & 120.1 & 23.0 & 37.0 & 0.0 & 1.48 & $<0.05$ & 131.5 \\
\hline $\mathrm{TiO}_{2}$ & 167 & 17.7 & 43.9 & 0.0 & 0.42 & 0.53 & 103.7 & 16.5 & 44.5 & 0.0 & 1.06 & 0.16 & 102.1 \\
\hline $\mathrm{ZrO}_{2}$ & 143 & 8.2 & 57.8 & 0.0 & 0.16 & 0.21 & 117.5 & 7.8 & 57.5 & 0.0 & 0.49 & $<0.05$ & 107.1 \\
\hline AZF & 120 & 36.1 & 1.4 & 22.8 & 0.22 & 2.38 & 28.1 & 38.4 & 1.31 & 20.1 & 2.57 & $<0.05$ & 16.8 \\
\hline SBA & 743 & 25.7 & 0.0 & 22.6 & 0.45 & 1.92 & 339.0 & 36.8 & 0.0 & 22.6 & 2.07 & $<0.05$ & 340.1 \\
\hline BEA & 680 & 28.3 & 1.9 & 27.5 & 0.31 & 1.47 & 331.7 & 24.8 & 1.81 & 25.9 & 1.07 & $<0.05$ & 330.5 \\
\hline
\end{tabular}

When using the AZF support, the main purpose was to achieve a higher possible molybdenum loading to get a composite material with large cavities (up to tens of micrometres) filled with molybdenum carbide or nitride crystal particles. This was reasoned by the fact that the larger particles of carbide and nitride phases have better stability during the reactions and increased resistance to complete oxidation to crystalline metal oxides [49,50]. These materials were characterized by having the lowest specific surface area $\left(16-28 \mathrm{~m}^{2} / \mathrm{g}\right)$, determined mainly by the surface of the bulk nitride or carbide phases located in macroporous cavities of the AZF support. The significant decrease of the area from the original was due to clogging micropores, as is the case of the BEA samples. However, there was no noticeable difference in comparing nitride and carbide samples in $\mathrm{S}_{\mathrm{BET}}$ reduction. Both groups showed very similar surface area values without any prevalence in blocking pores (Table 3 ).

The carbides except supported on $\mathrm{TiO}_{2}(0.16 \%$ of $\mathrm{N})$ contained no nitrogen, or below the detection limit of the device. The carbon content varied between 0.49 and $2.57 \%$ for all samples. A small 
amount of carbon $(0.08-0.45 \%)$ was inherent for each nitride sample and nitrogen was in similar values $(0.21-2.38 \%)$ as carbon in carbides (Table 3$)$. The low nitrogen and carbon contents could be caused by low amounts of impregnating complexes on $\mathrm{ZrO}_{2}$ and $\mathrm{TiO}_{2}$, which in turn was due to their low pore volumes.

XRD results (Figure 16) showed that when $\mathrm{Al}_{2} \mathrm{O}_{3}$ was used as the support, well-dispersed carbides and nitrides phases were formed. In carbides samples, apart from $\alpha-\mathrm{Mo}_{2} \mathrm{C}$ and $\mathrm{Al}_{2} \mathrm{O}_{3}$, the main phase was detected as amorphous. The nitrides, besides the main amorphous phase, also contained $\beta-\mathrm{Mo}_{2} \mathrm{~N}$ accompanied by cubic $\mathrm{Mo}_{3} \mathrm{~N}_{2}$ and $\mathrm{Al}_{2} \mathrm{O}_{3}$. In addition, the formation of a certain proportion of a cubic AlN phase cannot be excluded. The phase composition of $\mathrm{MoC}_{\mathrm{x}}$ on $\mathrm{Al}_{2} \mathrm{O}_{3}{ }^{\#}$ and $\mathrm{Al}_{2} \mathrm{O}_{3}$ was identical, but in the case of $\mathrm{MoN}_{\mathrm{x}}$, the samples differed by predominant monoclinic $\mathrm{MoO}_{2}$ on $\mathrm{Al}_{2} \mathrm{O}_{3}{ }^{\#}$. The synthesis of $\mathrm{Al}_{2} \mathrm{O}_{3}{ }^{\#}$ supported materials is more often used than the method with precursor complexes due to its simplicity [51-53]. However, in the case of nitrides, there was no complete conversion to the desired phase in these conditions. $\mathrm{TiO}_{2}$, in the case of carbide preparation, comprised the crystalline phase of anatase accompanied by the well-dispersed carbide phase containing $\alpha-\mathrm{Mo}_{2} \mathrm{C}$ and $\beta-\mathrm{Mo}_{2} \mathrm{C}$ in the ratio of 40:60. The possible formation of a small fraction of the cubic delta phase cannot be excluded. The nitride pathway led the $\beta-\mathrm{Mo}_{2} \mathrm{~N}$ phase accompanied by cubic $\mathrm{Mo}_{3} \mathrm{~N}_{2}$. The dominant crystalline phase was anatase. A shift of the peak at about $38^{\circ} 2$ theta to the right can be explained as a partial overlapping of the carbide/nitride peak with the anatase phase of the support. A similar composition of the active phases was observed on $\mathrm{ZrO}_{2}$, which due to the small pore volume, contained only about half of the amount of molybdenum against the $\mathrm{TiO}_{2}$ support. The proportion of the carbide phases was identical, whereas, for nitrides, it was not possible to exclude the presence of the gamma phase. At the carbide pathway, the SBA-15 mesoporous silica provided a mixture of $\alpha-\mathrm{Mo}_{2} \mathrm{C}$ and $\beta-\mathrm{Mo}_{2} \mathrm{C}$ at a ratio of about 40:60; in the case of the nitride pathway, there was a cubic $\mathrm{Mo}_{3} \mathrm{~N}_{4}$ and a part of the monoclinic $\mathrm{MoO}_{2}$. The diffractogram, when measuring low angles, shows that the mesoporous structure was preserved (Figure 16). The obtained diffractograms also show the presence of reflections characteristic of microporous zeolite Beta and well-dispersed $\beta-\mathrm{Mo}_{2} \mathrm{C}$ and cubic $\mathrm{Mo}_{3} \mathrm{~N}_{2}$ of carbide and nitride samples, respectively. Diffractograms of the samples prepared on AZF support show the presence of the zeolite phase (clinoptilolite) and crystalline $\alpha-\mathrm{Mo}_{2} \mathrm{C}$ and $\beta-\mathrm{Mo}_{2} \mathrm{C}$ (approximately 60:40) and $\beta-\mathrm{Mo}_{2} \mathrm{~N}$, respectively. The influence of the support acidity on the formation of carbide or nitride phases was not clear. On the more acidic supports, in the case of carbides, a mixture of $\alpha$ and $\beta$ - phases was produced, while in the mixed nitride phase, the crystalline cubic phase of $\mathrm{Mo}_{3} \mathrm{~N}_{2}$ was observed.

The microphotographs from the optical and electron microscope (Figures 17 and 18) show the structure of the prepared supported samples. The composite samples on AZF had macroporous cavities filled with crystalline carbides (Figure 17). The porous structure did not change, even after heat treatment at $700{ }^{\circ} \mathrm{C}$. On the detailed SEM image, a sponge-like structure with a large number of small pores is clearly visible. The samples prepared on the SBA-15 support are shown in Figure 18. A regular structure of the mesoporous silica SBA-15 was not disordered during the preparation of the carbides or nitrides, even at $700{ }^{\circ} \mathrm{C}$. Its surface was formed by nitride or carbide crystals, probably shaped by precursor leakage from the cylindrical pores during heat treatment. The TEM image of carbided SBA-15 (Figure 18b) clearly shows in detail the basic mesoporous structure of SBA-15 that contained the $\mathrm{MoC}_{\mathrm{x}}$ nanocrystals inside the cylindrical pores and outside on the catalyst surface. Moreover, the dramatic decrease in the surface area of SBA- 15 was confirmed by TEM, as the blockage caused by the formation of crystals inside the long cylindrical mesoporous structure of the support (Figure 18b). 
a)

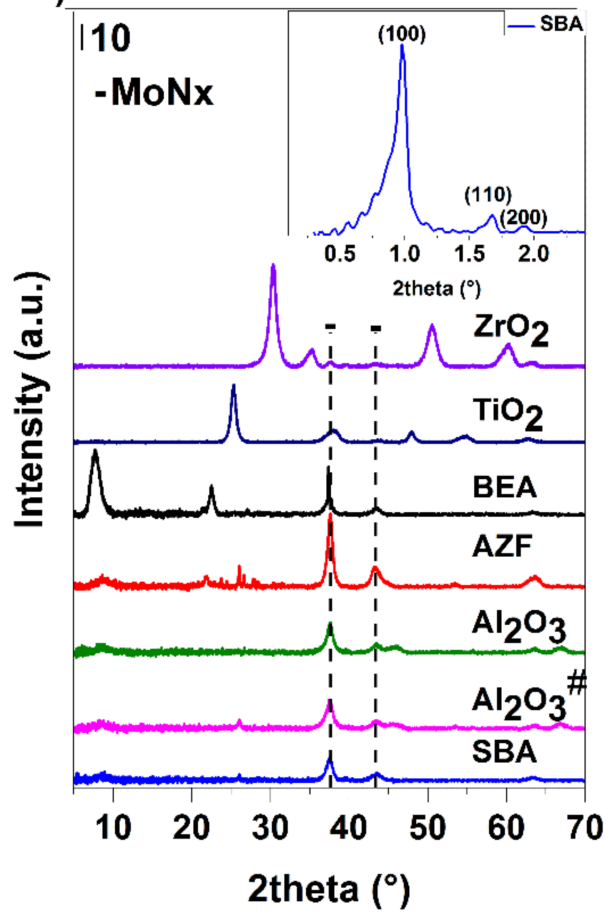

b)

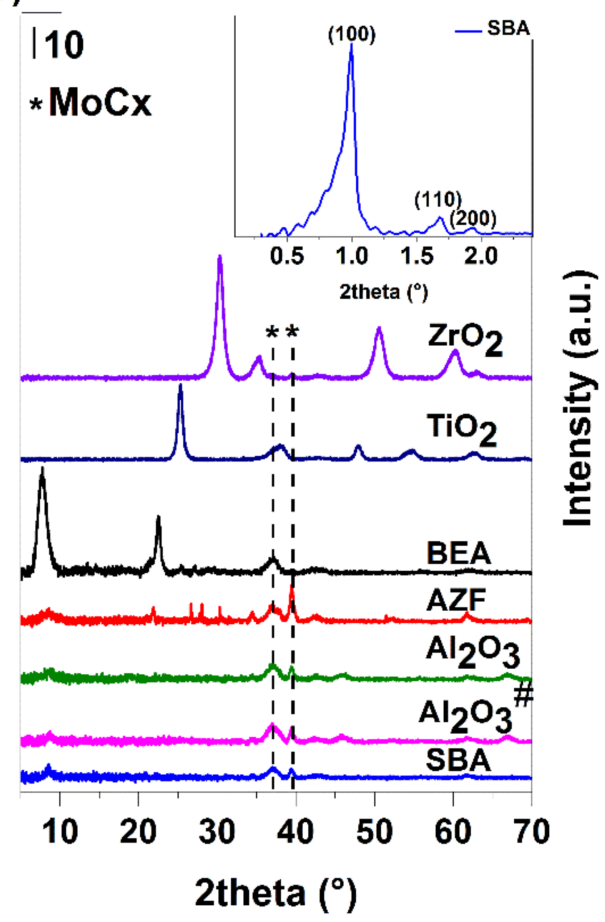

Figure 16. X-ray diffraction patterns of the supported catalysts prepared by different pathways: nitrides (a) and carbides (b).

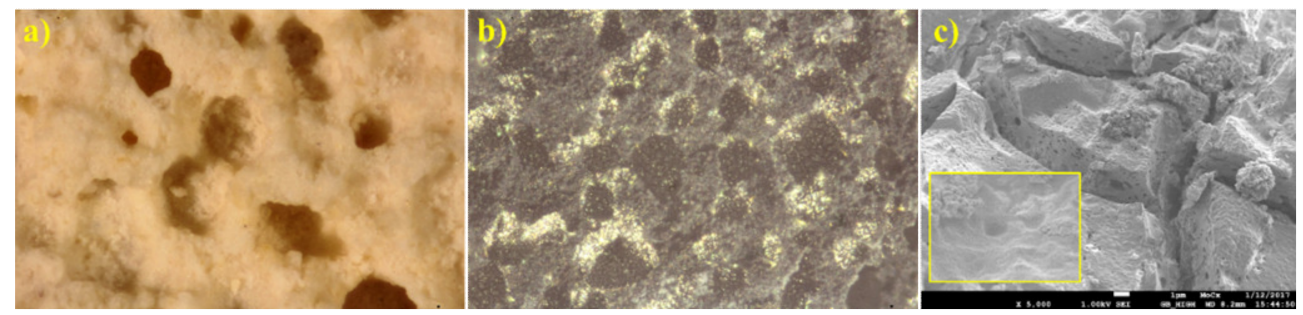

Figure 17. Microphotographs of the samples at $6.3 \times$ magnification for (a) foamed AZF support, (b) carbided AZF composite, and (c) detailed structure of the carbide layer made by SEM $(5000 \times$ and $100,000 \times)$.
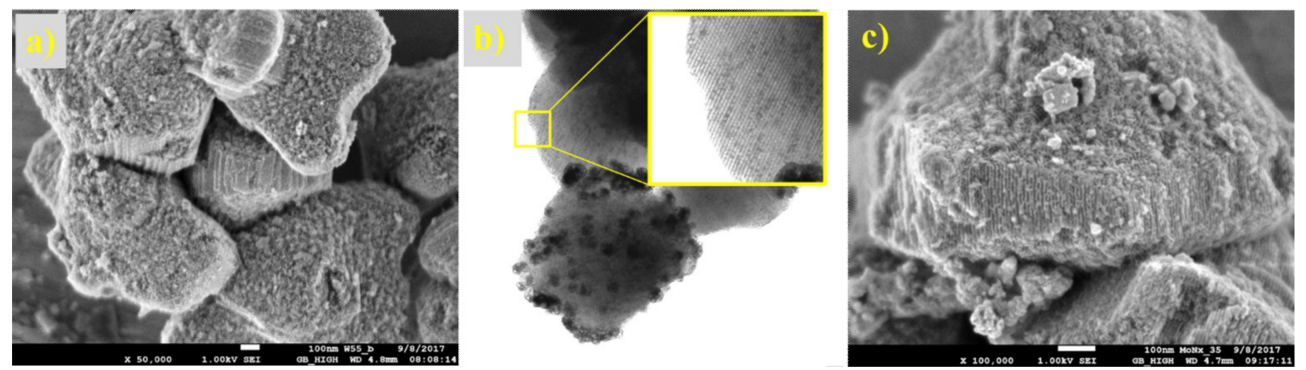

Figure 18. Microphotographs of the samples supported on SBA-15 for (a) SEM of the carbide sample $(50,000 \times),(\mathbf{b})$ TEM of the carbide sample, and (c) SEM of the nitride sample $(100,000 \times)$

The non-supported nitride sample was applied by Murzin's group in the direct hydrodeoxygenation of algal lipids extracted from Chlorella alga, and found to be a perspective catalyst [54]. Other samples have been tested in different hydrotreatment reactions under batch and flow conditions conducted at UniCRE. Further evaluation of the results are under the publishing process. 
According to the literature $[22,35,36,44,45,55-69]$, the main precursor for the synthesis of supported molybdenum catalysts with the nitride or carbide active phases is considered to be AHM $\left(\mathrm{MoO}_{3}\right)$, and less often the mixture of HMT with AHM, while the preparation of supported catalysts by the impregnation of the HMT-AHM complex is not practically used. AHM impregnated supports are initially calcined in the air to form $\mathrm{MoO}_{3}$ on the surface of the support. The most commonly used one is $\mathrm{Al}_{2} \mathrm{O}_{3}$ followed by $\mathrm{SiO}_{2} / \mathrm{SBA}-15$. In the case of $\mathrm{Mo}_{2} \mathrm{C}$ containing catalysts, carbon (activated carbon, carbon black, nanotubes, etc.) is preferably used, which contributes to the formation of the carbide phase on the support surface.

\section{Conclusions}

This study set out the possibility of molybdenum carbide and nitride synthesis using various precursors and reaction conditions. Based on the analysis of the studied supported and bulk materials, the most suitable preparation conditions to obtain the desired phases were considered. The ability to prepare carbide and nitride phases was demonstrated on the commonly used supports $\mathrm{Al}_{2} \mathrm{O}_{3}, \mathrm{TiO}_{2}, \mathrm{ZrO}_{2}, \mathrm{SBA}-15$, and zeolite Beta, and also on the less common AZF support. It was investigated that the synthesis of target molybdenum nitrides strongly depends on the structure of the precursor and temperature conditions, while the synthesis of carbide samples always led to the target phase composition. Unlike the carbide samples, where the $\alpha-\mathrm{Mo}_{2} \mathrm{C}$ phase was predominant during nitridation, the mixture of $\beta-\mathrm{Mo}_{2} \mathrm{~N}$ and $\mathrm{MoO}_{2}$ with a small amount of metal molybdenum was generally formed. However, using the precursor complex obtained from the mixture of hexamethylenetetramine with ammonium heptamolybdate (HMT-AHM), the pure phase of molybdenum nitride was achieved at $800{ }^{\circ} \mathrm{C}$. At $700{ }^{\circ} \mathrm{C}, \gamma-\mathrm{Mo}_{2} \mathrm{~N}$ with a small amount of $\alpha-\mathrm{Mo}_{2} \mathrm{C}$ was formed from the same precursor. A similar situation occurred when using the precursor synthesized by evaporation of the ammonia solution of HMT with AHM at a molar ratio of 2:1, where the resulting cubic $\mathrm{Mo}_{3} \mathrm{~N}_{2}$ phase was also accompanied by a small amount of $\alpha-\mathrm{Mo}_{2} \mathrm{C}$ at $700{ }^{\circ} \mathrm{C}$. Supported samples, even at the high molybdenum content, had the high dispersion of the phases. All carbide samples were composed of $\alpha$ - and $\beta-\mathrm{Mo}_{2} \mathrm{C}$ mixtures. Nitrides supported on $\mathrm{Al}_{2} \mathrm{O}_{3}$ consisted of $\beta-\mathrm{Mo}_{2} \mathrm{~N}$, and on $\mathrm{TiO}_{2}$ and $\mathrm{ZrO}_{2}$ consisted of $\beta$ - and $\gamma-\mathrm{Mo}_{2} \mathrm{~N}$ mixtures, SBA-15, and BEA, despite the $\beta$ - and $\gamma$-phases also containing $\mathrm{Mo}_{3} \mathrm{~N}_{2}$ and $\mathrm{Mo}_{3} \mathrm{~N}_{4}$. The composite samples prepared on the foamed AZF support included cavities filled with crystalline $\alpha$ - and $\beta-\mathrm{Mo}_{2} \mathrm{C}$ in the case of carbides and the $\beta-\mathrm{Mo}_{2} \mathrm{~N}$ crystalline phase for nitrides.

Author Contributions: Conceptualization, design of the experiments, analysis of the data, writing-original draft preparation, Z.T.; synthesis, L.S.; analytical measuring, R.V. and L.P.; supervision, writing-review and editing, U.A.

Funding: The publication is a result of the project Development of the UniCRE Centre (LO1606), which has been financially supported by the Ministry of Education, Youth, and Sports of the Czech Republic (MEYS) under the National Sustainability Program I. The result was achieved using the infrastructure of the project Efficient Use of Energy Resources Using Catalytic Processes (LM2015039), which has been financially supported by MEYS within the targeted support of large infrastructures.

Acknowledgments: Special thanks to the University of Pardubice (Czech Republic) for SEM images processing, to the Åbo Akademi Process Chemistry Centre (Finland), and Markus Peurla (University of Turku, Finland) for the TEM analysis.

Conflicts of Interest: The authors declare no conflict of interest.

\section{References}

1. Calaisa, J.L. Band structure of transition metal compounds. Adv. Phys. 1977, 26, 847-885. [CrossRef]

2. Wu, M.; Lin, X.; Hagfeldt, A.; Ma, T. Low-cost molybdenum carbide and tungsten carbide counter electrodes for dye-sensitized solar cells. Angew. Chem. Int. Ed. 2011, 50, 3520-3524. [CrossRef]

3. Oyama, S.T. Preparation and catalytic properties of transition metal carbides and nitrides. Catal. Today 1992, 15, 179-200. [CrossRef] 
4. Furimsky, E. Metal carbides and nitrides as potential catalysts for hydroprocessing. Appl. Catal. A Gen. 2003, 240,1-28. [CrossRef]

5. Abe, H.; Cheung, T. Keung; Bell, A.T. The activity of transition metal nitrides for hydrotreating quinoline and thiophene. Catal. Lett. 1993, 21, 11-18. [CrossRef]

6. Zhao, Y.; Kamiya, K.; Hashimoto, K.; Nakanishi, S. In situ $\mathrm{CO}_{2}$-emission assisted synthesis of molybdenum carbonitride nanomaterial as hydrogen evolution electrocatalyst. J. Am. Chem. Soc. 2015, 137, 110-113. [CrossRef] [PubMed]

7. Neylon, M.K.; Choi, S.; Kwon, H.; Curry, K.E.; Thompson, L.T. Catalytic properties of early transition metal nitrides and carbides: N-butane Hydrogenolysis, dehydrogenation and isomerization. Appl. Catal. A Gen. 1999, 183, 253-263. [CrossRef]

8. Al Shalwi, M. The Preparation of Molybdenum Carbonitrides by Single Source Routes and a Study of Their Lattice. Master's Thesis, University of Glasgow, Glasgow, UK, May 2012.

9. Oyama, S.T. Introduction to the chemistry of transition metal carbides and nitrides. In The Chemistry of Transition Metal Carbides and Nitrides; Springer: Berlin, Germany, 1996; pp. 1-27.

10. Nakajima, T. Chemical vapor deposition of tungsten carbide, molybdenum carbide nitride, and molybdenum nitride films. J. Electrochem. Soc. 1997, 144, 2096. [CrossRef]

11. Hyeon, T.; Fang, M.; Suslick, K.S. Nanostructured molybdenum carbide: Sonochemical synthesis and catalytic properties. J. Am. Chem. Soc. 1996, 118, 5492-5493. [CrossRef]

12. Pang, M.; Li, C.; Ding, L.; Zhang, J.; Su, D.; Li, W.; Liang, C. Microwave-assisted preparation of $\mathrm{Mo}_{2} \mathrm{C} / \mathrm{CNTs}$ nanocomposites as efficient electrocatalyst supports for oxygen reduction reaction. Ind. Eng. Chem. Res. 2010, 49, 4169-4174. [CrossRef]

13. Bystrov, Y.A.; Vetrov, N.Z.; Lisenkov, A.A. Plasmachemical synthesis of carbide compounds in metal-containing plasma jet from vacuum arc discharge. Tech. Phys. Lett. 2008, 34, 734-736. [CrossRef]

14. Merzhanov, A.G.; Borovinskaya, I.P. Self-propagated high-temperature synthesis of refractory inorganic compounds. Doklady Akademii Nauk SSSR 1972, 204, 366-369.

15. Guil-López, R.; Nieto, E.; Botas, J.A.; Fierro, J.L.G. On the genesis of molybdenum carbide phases during reduction-carburization reactions. J. Solid State Chem. 2012, 190, 285-295. [CrossRef]

16. Schaidle, J.A.; Schweitzer, N.M.; Ajenifujah, O.T.; Thompson, L.T. On the preparation of molybdenum carbide-supported metal catalysts. J. Catal. 2012, 289, 210-217. [CrossRef]

17. Chai, S.H.; Schwartz, V.; Howe, J.Y.; Wang, X.; Kidder, M.; Overbury, S.H.; Dai, S.; Jiang, D.E. Graphitic mesoporous carbon-supported molybdenum carbides for catalytic hydrogenation of carbon monoxide to mixed alcohols. Microporous Mesoporous Mater. 2013, 170, 141-149. [CrossRef]

18. Tang, C.; Sun, A.; Xu, Y.; Wu, Z.; Wang, D. High specific surface area $\mathrm{Mo}_{2} \mathrm{C}$ nanoparticles as an efficient electrocatalyst for hydrogen evolution. J. Power Sources 2015, 296, 18-22. [CrossRef]

19. Vitale, G.; Guzmán, H.; Frauwallner, M.L.; Scott, C.E.; Pereira-Almao, P. Synthesis of nanocrystalline molybdenum carbide materials and their characterization. Catal. Today 2015, 250, 123-133. [CrossRef]

20. Preiss, H.; Meyer, B.; Olschewski, C. Preparation of molybdenum and tungsten carbides from solution derived precursors. J. Mater. Sci. 1998, 33, 713-722. [CrossRef]

21. Patel, M.; Subrahmanyam, J. Synthesis of nanocrystalline molybdenum carbide $\left(\mathrm{Mo}_{2} \mathrm{C}\right)$ by solution route. Mater. Res. Bull. 2008, 43, 2036-2041. [CrossRef]

22. Baklanova, O.N.; Vasilevich, A.V.; Lavrenov, A.V.; Drozdov, V.A.; Muromtsev, I.V.; Arbuzov, A.B.; Trenikhin, V.; Sigaeva, S.S.; Temerev, V.L.; Gorbunova, O.V.; et al. Molybdenum carbide synthesized by mechanical activation an inert medium. J. Alloys Compd. 2017, 698, 1018-1027. [CrossRef]

23. Torabi, O.; Golabgir, M.H.; Tajizadegan, H.; Torabi, H. A study on mechanochemical behavior of $\mathrm{MoO}_{3}-\mathrm{Mg}_{-} \mathrm{C}$ to synthesize molybdenum carbide. Int. J. Refract. Met. Hard Mater. 2014, 47, 18-24. [CrossRef]

24. Saghafi, M.; Ataie, A.; Heshmati-Manesh, S. Effects of mechanical activation of $\mathrm{MoO}_{3} / \mathrm{C}$ powder mixture in the processing of nano-crystalline molybdenum. Int. J. Refract. Met. Hard Mater. 2011, 29, 419-423. [CrossRef]

25. Khabbaz, S.; Honarbakhsh-Raouf, A.; Ataie, A.; Saghafi, M. Effect of processing parameters on the mechanochemical synthesis of nanocrystalline molybdenum carbide. Int. J. Refract. Met. Hard Mater. 2013, 41, 402-407. [CrossRef]

26. Choi, J.-G.; Brenner, J.R.; Colling, C.W.; Demczyk, B.G.; Dunning, J.L.; Thompson, L.T. Synthesis and characterization of molybdenum nitride hydrodenitrogenation catalysts. Catal. Today 1992, 15, 201-222. [CrossRef] 
27. Wolden, C.A.; Pickerell, A.; Gawai, T.; Parks, S.; Hensley, J.; Way, J.D. Synthesis of $\beta-\mathrm{Mo}_{2} \mathrm{C}$ thin films. ACS Appl. Mater. Interfaces 2011, 3, 517-521. [CrossRef] [PubMed]

28. Wang, T.; Liu, X.; Wang, S.; Huo, C.; Li, Y.W.; Wang, J.; Jiao, H. Stability of $\beta-\mathrm{Mo}_{2} \mathrm{C}$ facets from Ab initio atomistic thermodynamics. J. Phys. Chem. C 2011, 115, 22360-22368. [CrossRef]

29. Wang, T.; Wang, S.; Li, Y.W.; Wang, J.; Jiao, H. Adsorption equilibria of CO coverage on $\beta-\mathrm{Mo}_{2} \mathrm{C}$ surfaces. J. Phys. Chem. C 2012, 116, 6340-6348. [CrossRef]

30. Zhu, Q.; Chen, Q.; Yang, X.; Ke, D. A new method for the synthesis of molybdenum carbide. Mater. Lett. 2007, 61, 5173-5174. [CrossRef]

31. Vitale, G.; Frauwallner, M.L.; Hernandez, E.; Scott, C.E.; Pereira-Almao, P. Low temperature synthesis of cubic molybdenum carbide catalysts via pressure induced crystallographic orientation of $\mathrm{MoO}_{3}$ precursor. Appl. Catal. A Gen. 2011, 400, 221-229. [CrossRef]

32. Xiao, T.C.; York, A.P.E.; Williams, V.C.; Al-Megren, H.; Hanif, A.; Zhou, X.Y.; Green, M.L.H. Preparation of molybdenum carbides using butane and their catalytic performance. Chem. Mater. 2000, 12, 3896-3905. [CrossRef]

33. Bouchy, C.; Derouane-Abd Hamid, S.B.; Derouane, E.G. A new route to the metastable FCC molybdenum carbide $\alpha$-MoC. Chem. Commun. 2000, 125-126. [CrossRef]

34. Bouchy, C.; Schmidt, I.; Anderson, J.; Jacobsen, C.J.; Derouane, E.; Derouane-Abd Hamid, S. Metastable fcc $\alpha-\mathrm{MoC}_{1-\mathrm{x}}$ supported on HZSM5: Preparation and catalytic performance for the non-oxidative conversion of methane to aromatic compounds. J. Mol. Catal. A Chem. 2000, 163, 283-296. [CrossRef]

35. Miyao, T.; Shishikura, I.; Matsuoka, M.; Nagai, M.; Oyama, S.T. Preparation and characterization of alumina-supported molybdenum carbide. Appl. Catal. A Gen. 1997, 165, 419-428. [CrossRef]

36. Koós, Á.; Solymosi, F. Production of CO-free $\mathrm{H}_{2}$ by formic acid decomposition over $\mathrm{Mo}_{2} \mathrm{C} /$ carbon catalysts. Catal. Lett. 2010, 138, 23-27. [CrossRef]

37. Leclercq, L.; Provost, M.; Pastor, H.; Grimblot, J.; Hardy, A.M.; Gengembre, L.; Leclercq, G. Catalytic properties of transition metal carbides. I. Preparation and physical characterization of bulk mixed carbides of molybdenum and tungsten. J. Catal. 1989, 117, 371-383. [CrossRef]

38. Ma, Y.; Guan, G.; Shi, C.; Zhu, A.; Hao, X.; Wang, Z.; Kusakabe, K.; Abudula, A. Low-temperature steam reforming of methanol to produce hydrogen over various metal-doped molybdenum carbide catalysts. Int. J. Hydrogen Energy 2014, 39, 258-266. [CrossRef]

39. Bej, S.K.; Bennett, C.A.; Thompson, L.T. Acid and base characteristics of molybdenum carbide catalysts. Appl. Catal. A Gen. 2003, 250, 197-208. [CrossRef]

40. Lee, W.S.; Wang, Z.; Wu, R.J.; Bhan, A. Selective vapor-phase hydrodeoxygenation of anisole to benzene on molybdenum carbide catalysts. J. Catal. 2014, 319, 44-53. [CrossRef]

41. Lee, J.S.; Oyama, S.T.; Boudart, M. Molybdenum carbide catalysts. I. Synthesis of unsupported powders. J. Catal. 1987, 106, 125-133. [CrossRef]

42. Roy, A.; Serov, A.; Artyushkova, K.; Brosha, E.L.; Atanassov, P.; Ward, T.L. Facile synthesis of high surface area molybdenum nitride and carbide. J. Solid State Chem. 2015, 228, 232-238. [CrossRef]

43. Afanasiev, P. New single source route to the molybdenum nitride $\mathrm{Mo}_{2} \mathrm{~N}$. Inorg. Chem. 2002, 41, 5317-5319. [CrossRef] [PubMed]

44. Wang, Z.-Q.; Zhang, Z.-B.; Zhang, M.-H. The efficient synthesis of a molybdenum carbide catalyst via $\mathrm{H}_{2}$-thermal treatment of a Mo(VI)-hexamethylenetetramine complex. Dalton Trans. 2011, 40, 1098-1104. [CrossRef] [PubMed]

45. Wang, H.M.; Wang, X.H.; Zhang, M.H.; Du, X.Y.; Li, W.; Tao, K.Y. Synthesis of bulk and supported molybdenum carbide by a single-step thermal carburization method. Chem. Mater. 2007, 19, 1801-1807. [CrossRef]

46. Huo, X.; Wang, Z.; Huang, J.; Zhang, R.; Fang, Y. Bulk Mo and Co-Mo carbides as catalysts for methanation. Catal. Commun. 2016, 79, 39-44. [CrossRef]

47. Kovács, T.N.; Hunyadi, D.; de Lucena, A.L.A.; Szilágyi, I.M. Thermal decomposition of ammonium molybdates. J. Therm. Anal. Calorim. 2016, 124, 1013-1021. [CrossRef]

48. Chouzier, S.; Czeri, T.; Roy-Auberger, M.; Pichon, C.; Geantet, C.; Vrinat, M.; Afanasiev, P. Decomposition of molybdatehexamethylenetetramine complex: One single source route for different catalytic materials. J. Solid State Chem. 2011, 184, 2668-2677. [CrossRef] 
49. Stellwagen, D.R.; Bitter, J.H. Structure-performance relations of molybdenum- and tungsten carbide catalysts for deoxygenation. Green Chem. 2015, 17, 582-593. [CrossRef]

50. Alexander, A.-M.; Hargreaves, J.S.J. Alternative catalytic materials: Carbides, nitrides, phosphides and amorphous boron alloys. Chem. Soc. Rev. 2010, 39, 4388-4401. [CrossRef] [PubMed]

51. Wang, H.M.; Du, X.Y.; Zhang, M.H.; Li, W.; Tao, K.Y. Synthesis of bulk and alumina-supported $\gamma-\mathrm{Mo}_{2} \mathrm{~N}$ catalysts by a single-step complex decomposition method. Catal. Today 2008, 131, 156-161. [CrossRef]

52. Wang, H.; Li, W.; Zhang, M. New approach to the synthesis of bulk and supported bimetallic molybdenum nitrides. Chem. Mater. 2005, 17, 3262-3267. [CrossRef]

53. Wang, X.H.; Zhang, M.H.; Li, W.; Tao, K.Y. A simple synthesis route and characterisation of $\mathrm{Co}_{3} \mathrm{Mo}_{3} \mathrm{C}$. Dalt. Trans. 2007, 5165-5170. [CrossRef] [PubMed]

54. Nguyen, H.S.H.; Mäki-Arvela, P.; Akhmetzyanova, U.; Tišler, Z.; Hachemi, I.; Rudnäs, A.; Smeds, A.; Eränen, K.; Aho, A.; Kumar, N.; et al. Direct hydrodeoxygenation of algal lipids extracted from Chlorella alga. J. Chem. Technol. Biotechnol. 2017, 92, 741-748. [CrossRef]

55. Yao, Z.W. Exploration on synthesis of activated carbon supported molybdenum carbide, nitride and phosphide via carbothermal reduction route. J. Alloys Compd. 2009, 475, L38-L41. [CrossRef]

56. Pielaszek, J.; Mierzwa, B.; Medjahdi, G.; Marêché, J.F.; Puricelli, S.; Celzard, A.; Furdin, G. Molybdenum carbide catalyst formation from precursors deposited on active carbons: XRD studies. Appl. Catal. A Gen. 2005, 296, 232-237. [CrossRef]

57. Wang, X.H.; Hao, H.L.; Zhang, M.H.; Li, W.; Tao, K.Y. Synthesis and characterization of molybdenum carbides using propane as carbon source. J. Solid State Chem. 2006, 179, 538-543. [CrossRef]

58. Wu, Q.; Christensen, J.M.; Chiarello, G.L.; Duchstein, L.D.L.; Wagner, J.B.; Temel, B.; Grunwaldt, J.D.; Jensen, A.D. Supported molybdenum carbide for higher alcohol synthesis from syngas. Catal. Today 2013, 215, 162-168. [CrossRef]

59. Darujati, A.R.S.; Thomson, W.J. Stability of supported and promoted-molybdenum carbide catalysts in dry-methane reforming. Appl. Catal. A Gen. 2005, 296, 139-147. [CrossRef]

60. Du, X.; France, L.J.; Kuznetsov, V.L.; Xiao, T.; Edwards, P.P.; AlMegren, H.; Bagabas, A. Dry reforming of methane over $\mathrm{ZrO}_{2}$-supported Co-Mo carbide catalyst. Appl. Petrochem. Res. 2014, 4, 137-144. [CrossRef]

61. Vo, D.V.N.; Adesina, A.A. Fischer-Tropsch synthesis over alumina-supported molybdenum carbide catalyst. Appl. Catal. A Gen. 2011, 399, 221-232. [CrossRef]

62. McCrea, K.R.; Logan, J.W.; Tarbuck, T.L.; Heiser, J.L.; Bussell, M.E. thiophene hydrodesulfurization over alumina-supported molybdenum carbide and nitride catalysts: Effect of Mo loading and phase. J. Catal. 1997, 171, 255-267. [CrossRef]

63. Boullosa-Eiras, S.; Lødeng, R.; Bergem, H.; Stöcker, M.; Hannevold, L.; Blekkan, E.A. Catalytic hydrodeoxygenation (HDO) of phenol over supported molybdenum carbide, nitride, phosphide and oxide catalysts. Catal. Today 2014, 223, 44-53. [CrossRef]

64. Brungs, A.J.; York, A.P.E.; Claridge, J.B.; Márquez-Alvarez, C.; Green, M.L.H. Dry reforming of methane to synthesis gas over supported molybdenum carbide catalysts. Catal. Lett. 2000, 70, 117-122. [CrossRef]

65. Nagai, M.; Miyao, T.; Tuboi, T. Hydrodesulfurization of dibenzothiophene on alumina-supported molybdenum nitride. Catal. Lett. 1993, 18, 9-14. [CrossRef]

66. Colling, C.W.; Thompson, L.T. The structure and function of supported molybdenum nitride hydrodenitrogenation catalysts. J. Catal. 1994, 146, 193-203. [CrossRef]

67. Zhong, H.; Zhang, H.; Liu, G.; Liang, Y.; Hu, J.; Yi, B. A novel non-noble electrocatalyst for PEM fuel cell based on molybdenum nitride. Electrochem. Commun. 2006, 8, 707-712. [CrossRef]

68. Chen, X.; Zhang, T.; Xia, L.; Li, T.; Zheng, M.; Wu, Z.; Wang, X.; Wei, Z.; Xin, Q.; Li, C. Catalytic decomposition of hydrazine over supported molybdenum nitride catalysts in a monopropellant thruster. Catal. Lett. 2002, 79, 21-25. [CrossRef]

69. Tyrone Ghampson, I.; Sepúlveda, C.; Garcia, R.; García Fierro, J.L.; Escalona, N.; Desisto, W.J. Comparison of alumina- and SBA-15-supported molybdenum nitride catalysts for hydrodeoxygenation of guaiacol. Appl. Catal. A Gen. 2012, 435-436, 51-60. [CrossRef]

(C) 2019 by the authors. Licensee MDPI, Basel, Switzerland. This article is an open access article distributed under the terms and conditions of the Creative Commons Attribution (CC BY) license (http:/ / creativecommons.org/licenses/by/4.0/). 